\title{
1 Understanding aerosol composition in an inter-Andean valley 2 impacted by sugarcane intensive agriculture and urban emissions
}

Lady Mateus-Fontecha ${ }^{1}$, Angela Vargas-Burbano ${ }^{1}$, Rodrigo Jimenez*¹, Nestor Y. Rojas ${ }^{1}$, German Rueda$\mathrm{Saa}^{2}$, Dominik van Pinxteren ${ }^{3}$, Manuela van Pinxteren ${ }^{3}$, Khanneh Wadinga Fomba ${ }^{3}$, Hartmut Herrmann ${ }^{3}$

${ }^{1}$ Universidad Nacional de Colombia - Bogota, Department of Chemical and Environmental Engineering, Air Quality Research Group, Bogota, DC 111321, Colombia

${ }^{2}$ Universidad Nacional de Colombia - Palmira, Department of Engineering and Management, Environmental Prospective, Research Group, Palmira, Valle del Cauca 763533, Colombia

${ }^{3}$ Leibniz Institute for Tropospheric Research (TROPOS), Atmospheric Chemistry Department (ACD), Permoserstrasse. 15, 04318, Leipzig, Germany.

\section{Correspondence to: Rodrigo Jimenez (rjimenezp@unal.edu.co)}

\section{Abstract.}

Agro-industrial areas are frequently affected by various sources of atmospheric pollutants that negatively impact public health and ecosystems. However, air quality in these areas is infrequently monitored because of their lower population density compared to large cities, especially in developing countries. The Cauca River Valley (CRV) is an agro-industrial region in Southwest Colombia, where a large fraction of the area is devoted to sugarcane and derivatives production. CRV is also affected by road traffic and industrial emissions. This study aims to elucidate the chemical composition of particulate matter fine mode $\left(\mathrm{PM}_{2.5}\right)$ and to identify the main pollutant sources before source attribution. For this, a sampling campaign was carried out at a representative site of the CRV region, where daily-averaged mass concentrations of $\mathrm{PM}_{2.5}$ and the concentrations of water-soluble ions, trace metals, organic and elemental carbon, and various fractions of organic compounds (carbohydrates, n-alkanes, and polycyclic aromatic hydrocarbons - PAHs) were measured. Mean $\mathrm{PM}_{2.5}$ was $14.38 \pm 4.35 \mu \mathrm{g}$ $\mathrm{m}^{-3}$, and the most abundant constituent was organic material $(52.99 \% \pm 17.79 \%)$, followed by ammonium sulfate $(16.12 \% \pm$ $3.98 \%)$, and elemental carbon $(6.95 \% \pm 2.52 \%)$, which indicates secondary aerosol formation and incomplete combustion. Levoglucosan was present in all samples with a mean concentration of $\left(113.8 \pm 147.2 \mathrm{ng} \mathrm{m}^{-3}\right)$ revealing biomass burning as a persistent source. The diagnostic ratios applied to organic compounds revealed the influence of petrogenic and pyrogenic sources. Principal component analysis identified the influence of traffic-generated road dust, secondary aerosol formation, gasoline and diesel combustion vehicle exhaust, vegetative detritus, and resuspended agriculture soil. However, no single component was dominant nor explained the $\mathrm{CRV} \mathrm{PM}_{2.5}$ chemical species variance. Many components had equally important roles instead. Likewise, sugarcane pre-harvest burning, a frequent activity in CRV, was not identified as an independent 
component. This aerosol and trace gas source contributed to various components and was correlated to the formation of secondary aerosols.

Keywords: agro-industry; pre-harvest burning; $\mathrm{PM}_{2.5}$; chemical speciation; principal component analysis; Northern South America

\section{Introduction}

Due to their higher population and population density, air quality in urban areas has disproportionately received much more attention, from policymakers, governments, and researchers, than rural areas. Sometimes, this is grounded on the misconception that population sparsity implies lower exposure (Majra, 2011). Especially in developing countries, rural areas are the least monitored despite the widespread use of high emission practices, including the intensive use of insecticides/pesticides and fire for land and crop management (Aneja et al., 2008, 2009). Sprayed pesticides release volatile organic compounds (VOC) that can form tropospheric ozone (Majra, 2011) and secondary organic aerosols (SOA), while biomass burning emits fine particle matter (PM), black carbon (BC) and trace gases (including $\mathrm{CO}, \mathrm{CO}_{2}, \mathrm{SO}_{2}, \mathrm{NO}_{\mathrm{x}}, \mathrm{NH}_{3}$, VOC) that also generate $\mathrm{O}_{3}$ and SOA, all of which affect human health and climate (Yadav and Devi, 2019). Additionally, agricultural activities are a significant source of nitrogen-containing traces gases $\left(\mathrm{NO}_{2}, \mathrm{NO}, \mathrm{NH}_{3}, \mathrm{~N}_{2} \mathrm{O}\right)$ that are released into the atmosphere from fertilizers, livestock waste and farm machinery (Sutton et al., 2011).

Agricultural burning is worldwide used as an agriculture practice for rapidly and inexpensively clearing the land and for facilitating tillage and harvesting, so these can proceed unimpeded by external factors. This practice not only results in serious environmental local issues, like the increase of respiratory diseases for the population that is directly exposed, but also it is one of the main contributors to global atmospheric pollution (Abdurrahman et al., 2020). Biomass burning is common in tropical areas of Africa, South America, Asia, and Australia. Although widespread, open agricultural fires are typically shorter and less intense than forest fires, which make difficult their satellite detection and quantification (Pan et al., 2020). This has further hindered their observation and analysis. The pre-harvest burning of wheat, corn, rice residues, and sugarcane has been documented in Mexico(Mugica-Alvarez et al., 2015), Colombia, (Romero et al., 2013), Brazil (Lara et al., 2005; Vasconcellos et al., 2007) and Thailand (Janta et al., 2019). Sugarcane is a crop of global importance (26.8 million hectares in 2019) (FAO, 2020). About $80 \%$ of sugar and almost half of bio-ethanol worldwide are produced from sugarcane cultivated in more than 90 countries, most of them in the Global South but also in some developed economies, including Australia and USA. Sugarcane pre-harvest burning is still a very common practice worldwide. As other open-field biomass burning practices, sugarcane 
burning emits aerosols of high toxicity, secondary organic aerosol precursors and short-lived climate pollutants, among many other atmospheric contaminants.

Studying the airborne particulate matter chemical composition can be instrumental for the identification of pollutant sources, including agricultural burning, and the estimation of their contribution to the pollution burden. Most of the field measurement based studies have been conducted in North America, Europe, and Asia (Karagulian et al., 2015). The number of studies in Latin America and the Caribbean (LAC) is smaller and have focused on the chemical composition of $\mathrm{PM}_{10}$ (Pereira et al., 2019; Vasconcellos et al., 2011), and source apportionment in urban areas of Colombia (Ramírez et al., 2018; Vargas et al., 2012), Chile (Jorquera and Barraza, 2012, 2013; Villalobos et al., 2015), Costa Rica (Herrera Murillo et al., 2013) and Brazil (de Andrade et al., 2010). Previous PM chemical characterization studies in areas with pre- and post-harvest sugarcane burning have been conducted in Brazil (de Andrade et al., 2010; De Assuncao et al., 2014; Lara et al., 2005; Dos Santos et al., 2002; Souza et al., 2014; Urban et al., 2012, 2016), and México (Mugica-Alvarez et al., 2015; Mugica-Álvarez et al., 2016). Other studies have investigated the emissions from sugarcane burning in combustion chambers for $\mathrm{PM}_{10}, \mathrm{PM}_{2.5}$, Elemental Carbon (EC), Organic Carbon (OC) and PAH (Hall et al., 2012; Jenkins et al., 1992; Mugica-Álvarez et al., 2018). Research in Colombia is scarce (Romero et al., 2013), even though communities, environmental authorities, and the scientific community have long recognized the public health, environmental, and climate impacts of open sugarcane burning, especially in the Cauca River Valley (CRV).

CRV is an inter-Andean valley in Southwest Colombia with a flat area of $5287 \mathrm{~km}^{2}$ (248-km long by 22-km mean width), at a mean altitude of $985 \mathrm{~m}$ MSL (Figure 1), bounded by the Colombian Andes Western and Central Cordilleras, and located at $\sim 120 \mathrm{~km}$ from and meteorologically influenced by the Pacific Ocean. CRV encompasses the cities of Cali, Colombia's thirdlargest city with 2.2 million inhabitants (hab), Yumbo (129 khab), an important industrial hub, and Palmira (313 khab), which is the centroid of extensive sugarcane plantations. CRV hosts a highly efficient, resource-intensive sugarcane agro-industry, with one of the highest biomass yields and the highest sugar productivity in the World ( 13 ton sugar/ha) (Asocaña, 2018, 2019). The sugarcane agro-industry produced $3.7 \%$ of Colombia's agricultural gross domestic product (GDP) and $2.2 \%$ of its industrial GDP (0.6\% of the total GDP) in 2019 (Asocaña, 2019). In 2018 the sugarcane harvest was 195,346 ha, of which $25 \%$ belong to 15 sugar mills and $75 \%$ to private owners. The production rate was 119.61 sugarcane ton/ha in 2018 and the average size of each crop is $63 \mathrm{ha}$, to produce powdered sugar and ethanol used as biofuel. A fraction (45\%) of sugarcane is harvested using a mechanical method and the other fraction (55\%) with a manual labor method (Asocaña, 2020). In the manual method, the crops are burned for some minutes to facilitate the process of cane cutters and this manual harvest also is used as a socioeconomic tool to provide low-skilled employment to the population of the region. About 69,272 ha ( 8.3 Mt) of sugarcane were burnt in 2018, thus contributing to the emissions of particulate matter (PM) and gases (Cardozo-Valencia et al., 2019). Since 6.1 Mt of sugarcane bagasse are used to generate electricity (1,657 GWh), this adds additional emissions of organic components in gases and PM (Asocaña, 2020). Additionally, either pre-harvest burned or not, harvested sugarcane is 
transported to mills in multi-car trailers towed by diesel-powered crawlers. The crawler fleet is aged and numerous enough, and with sufficient annual activity, to potentially constitute an independent source with its own emission chemical profile, similar to other diesel sources, but with its activity tied to sugarcane harvesting.

For this research purposes only, we made a preliminary estimation of the aggregated $\mathrm{PM}_{10}$ emissions in CRV by putting together disparate source data, including the stationary source emission inventories of CRV's six largest cities excluding Palmira (Cali, Tulua, Cartago, Jamundi, Yumbo and Buga), Cali's and other cities mobile source emission inventories and an estimation of sugarcane pre-harvest burning emissions (Cardozo-Valencia et al., 2019), (Table S1). Our preliminary estimation indicates that the manufacturing industry, with annual emissions of 10.5 kton $\mathrm{PM}_{10}$, is the largest $\mathrm{PM}_{10}$ emitter in CRV. PM 10 emissions from mobile sources (3.12 kton $\mathrm{PM}_{10}$ year $\left.^{-1}\right)$ and open-field sugarcane burning $\left(1.3 \mathrm{kton} \mathrm{PM}_{10}\right.$ year $\left.{ }^{-1}\right)$ are a factor $\sim 3$ and $\sim 8$ smaller, respectively. Nonetheless, it is worth mentioning the following: 1) The available information was insufficient for $\mathrm{PM}_{2.5}$ emission estimation; 2) No emission data were available on Palmira, the city in which our measurement site is located; 3) The stationary emission inventory of Yumbo, an industrial hub with the largest industrial activity, is outdated and very likely overestimated, particularly as a significant fraction of coal-fired boilers there have been retrofitted to natural gas. This pollutant source multiplicity, disparity, and uncertainty are indicative of the complexity of the $\mathrm{PM}_{2.5}$ source identification, quantification and location tasks.

This research aimed to characterize the chemical composition of $\mathrm{PM}_{2.5}$ at a representative location of $\mathrm{CRV}$, including elemental carbon (EC), primary and secondary organic carbon (OC), ions, trace metals, and specific molecular markers, including polycyclic aromatic hydrocarbons (PAH), n-alkanes, and carbohydrates, and to understand the relationships among these components and with emission sources. Diagnostic ratios and principal component analysis were used to identify the most important $\mathrm{PM}_{2.5}$ components and as a tool for preliminary pollutant source identification, including primary and secondary aerosols generated by or associated with sugarcane pre-harvest burning (PHB). We believe that in the CRV case, this analysis is needed prior to source apportionment with receptor models for three reasons: 1) This is the first comprehensive investigation of particulate matter composition in CRV (prior studies included two types of components at most); 2) There are no suitable chemical profiles for some pollutant sources, particularly sugarcane PHB; 3) Our measurements dataset is just barely large for profile-free receptor modeling (positive matrix factorization). Our results are particularly relevant for urban communities and atmospheres impacted by large-scale intensive agriculture and industrial emissions, particularly in developing countries, especially in Latin America where PM composition information is still sparse. 


\section{Methods}

\section{2.1. Description of the sampling site}

128 The sampling site was located on the rooftop of an 8-story administrative building at the Palmira Campus of Universidad

129 Nacional de Colombia ( $3^{\circ} 30^{\prime} 44.26^{\prime \prime} \mathrm{N} ; 7^{\circ} 18^{\prime} 27.40^{\prime \prime} \mathrm{W}, 1065 \mathrm{~m}$ altitude), about $27 \mathrm{~m}$ above the ground. The Campus is located at the west edge of Palmira's urban area $(311 \mathrm{khab})$, and is surrounded by short buildings at the east and extensive sugarcane plantations, several sugar mills, and other industries elsewhere. Palmira is located at $\sim 27 \mathrm{~km}$ northeast of Cali $(2.2$ Mhab) and $22 \mathrm{~km}$ southeast of Yumbo (123 khab), an important industrial hub. The Pacific Ocean coastline is located at $\sim 120$ $\mathrm{km}$ across the Western Cordillera, as shown in Figure 1. on the Pacific Ocean coast is one most important international trade seaports in Colombia. Most of the freight is transported by diesel-powered trucks. Road traffic is also substantial within CRV, with Bogota and along the Pan-American highway that connects Colombia with other South American countries .

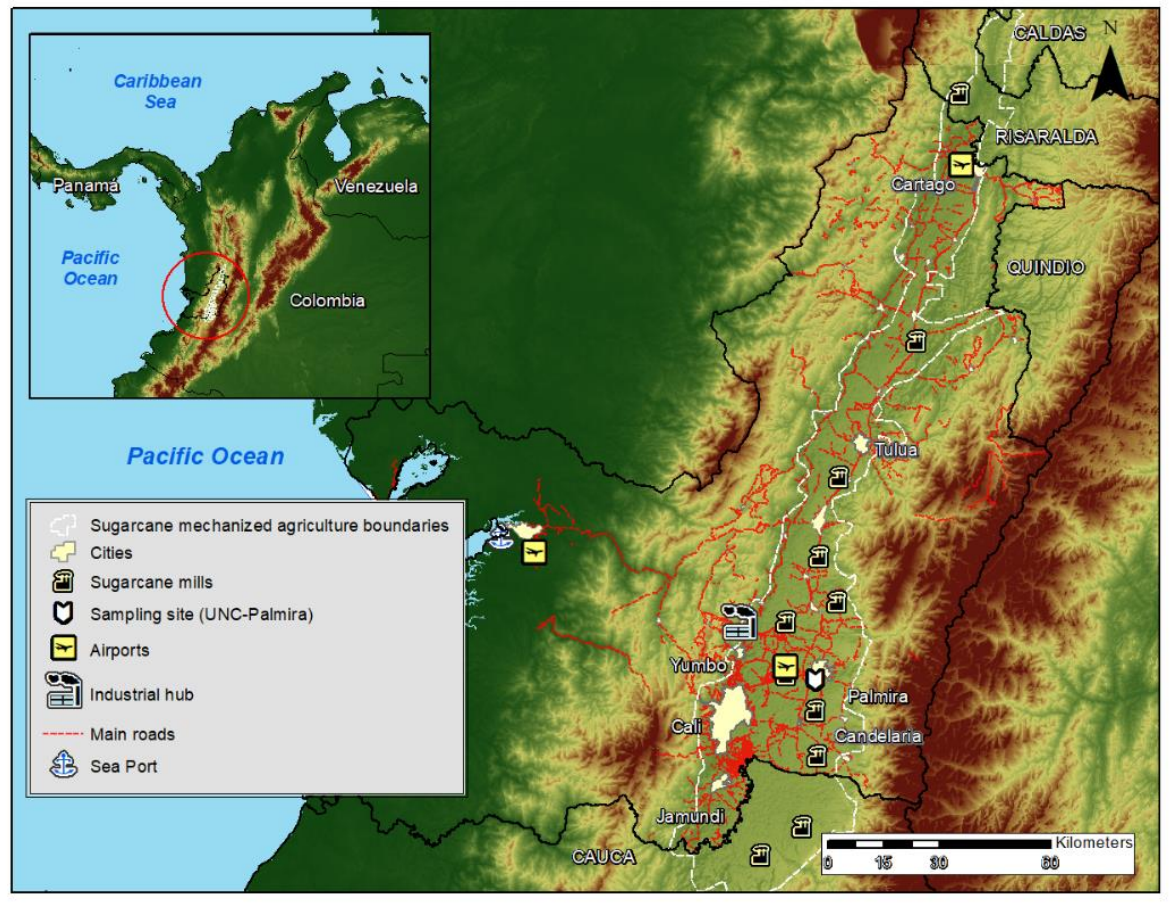

138 Figure 1. Map of the Cauca River Valley (CRV). The inset shows the location of CRV in Colombia and in Northern South

139 America. The map shows the main cities in CRV, including Palmira (312 thousand inhabitants), our measurement site, and

140 Cali, the most important city in the southwest of Colombia with 2.2 million inhabitants, Yumbo, an industrial hub, and the 141 main highways. Sugar mills, which produce sugar, bio-ethanol, and electric power are also shown. The dash-line delimited 142 area is the CRV's flattest (slope < 5\%) bottomland, where mechanized, intensive sugarcane agriculture takes place. 
Buenaventura on the Pacific Ocean is one of the busiest ports in Colombia, thus significant diesel combustion emissions occur along the Buenaventura highway.

\subsection{Sampling protocols}

The sampling campaign was conducted between $25^{\text {th }}$ July and $19^{\text {th }}$ September 2018 . $\mathrm{PM}_{2.5}$ aerosol particles (aerodynamic diameter $<2.5 \mu \mathrm{m}$ ) were simultaneously collected on Teflon and quartz fiber filters for $23 \mathrm{~h}$ (from 12:00 local time - LT - to the following day at 11:00 LT), using 2 in-tandem low-volume samplers (ChemComb speciation samplers, R\&P). Each sampler used an independent pump set at a flowrate of $14 \mathrm{~L} \mathrm{~min}^{-1}$. Quartz filters were pre-baked at $600{ }^{\circ} \mathrm{C}$ for $8 \mathrm{~h}$ before sampling to eliminate contaminant trace hydrocarbons. In total, 45 samples were collected. Prior to and after exposure, the filters were conditioned at constant humidity $\left(36 \pm 1.5 \%\right.$ relative humidity) and temperature $\left(24 \pm 1.2{ }^{\circ} \mathrm{C}\right)$ for $24 \mathrm{~h}$ before weighing them on a microbalance (Sartorius, Mettler Toledo) with $199.99 \mathrm{~g}$ capacity and $10 \mu \mathrm{g}$ resolution. Particulate matter loaded filters were stored at $-20^{\circ} \mathrm{C}$ until analysis. Mass concentrations were determined from the Teflon filters by differential weighting. It is worth mentioning that 1888 sugarcane pre-harvest burning events took place during the sampling period. The vast majority of these events were intentional, controlled, size-limited ( $\sim 6$ ha median area), and short ( 25 minutes median duration) (Fig S1).

\subsection{Analytical methods}

The quartz-fiber filter samples were analyzed for ions, elemental and organic carbon, and speciation of the carbonaceous fraction. The Teflon-membrane filter samples were analyzed for metals.

Two circular pieces of quartz filter of $8 \mathrm{~mm}$ diameter $\left(100.5 \mathrm{~mm}^{2}\right)$ were punched from the filter and extracted using $1 \mathrm{~mL}$ of ultrapure water $(18 \mathrm{M} \Omega)$ in a shaker at $400 \mathrm{rpm}$ for $120 \mathrm{~min}$. The extracts were filtered through $0.45 \mu \mathrm{m}$ syringe filters (Acrodisc Pall). An aliquot of the solution was analyzed for inorganic $\left(\mathrm{K}^{+}, \mathrm{Na}^{+}, \mathrm{NH}_{4}^{+}, \mathrm{Mg}^{2+}, \mathrm{Ca}^{2+}, \mathrm{Cl}^{-}, \mathrm{NO}_{3}^{-}, \mathrm{SO}_{4}{ }^{2-}, \mathrm{NO}_{2}{ }^{-}\right.$, $\left.\mathrm{PO}_{4}{ }^{3-}, \mathrm{Br}, \mathrm{F}^{-}\right)$and some organic ions $\left(\mathrm{C}_{2} \mathrm{O}_{4}{ }^{2-}, \mathrm{CH}_{3} \mathrm{O}_{3} \mathrm{~S}^{-}\right.$, and $\mathrm{CHO}_{2}{ }^{-}$) by ion chromatography (IC690 Metrohm; ICS3000, Dionex). Another aliquot was analyzed for carbohydrates, including levoglucosan, mannosan, and galactosan, as described by Iinuma et al. (2009a). Organic and elemental carbon was determined from $90.0 \mathrm{~mm}^{2}$ filter pieces following the EUSAAR 2 protocol (Cavalli et al., 2010), with a thermal-optical method using a Sunset Laboratory dual carbonaceous analyzer.

Seventeen metals including $\mathrm{K}, \mathrm{Ca}, \mathrm{Ti}, \mathrm{V}, \mathrm{Cr}, \mathrm{Mn}, \mathrm{Fe}, \mathrm{Ni}, \mathrm{Cu}, \mathrm{As}, \mathrm{Se}, \mathrm{Sr}, \mathrm{Ba}, \mathrm{Pb}, \mathrm{Sn}, \mathrm{Sb}$, and $\mathrm{Cu}$ were analyzed from Teflon and quartz filters by total reflection X-Ray Fluorescence Spectroscopy - TRXF (TXRF, PICOFOX S2, Bruker). Si was not determined as this element makes part of the quartz filter substrate. Metals were analyzed from three 8-mm circular pieces punched from the 45 filters, after their digestion with a nitric and chloride acid solution for 180 min to $180{ }^{\circ} \mathrm{C}$. After this, 20 

solution, which served as internal standard. This solution was left to evaporate at $100^{\circ} \mathrm{C}$. The samples were measured at two angles with a difference of $90^{\circ}$ between them to ensure complete excitation of metals. More details on the analytical technique can be found in Fomba et al. (2013).

Alkanes and polycyclic aromatic hydrocarbons (PAH) were determined from two circular pieces of filter (6 mm diameter, 56.5 $\mathrm{mm}^{2}$ ), using a Curie-point pyrolyzer (JPS-350, JAI) coupled to a GC-MS system (6890 N GC, 5973inert MSD, Agilent

Technologies). The chemical identification and quantification of the $\mathrm{C}_{20}$ to $\mathrm{C}_{34} \mathrm{n}$ alkanes, along with the following organic species were performed using the following external standards (Campro, Germany): pristane, phytane, fluorene (FLE), phenanthrene (PHEN), anthracene (ANT), fluoranthene (FLT), pyrene (PYR), retene (RET), benzo(b)naphtho(1,2-d)thiophene (BNT $(2,1))$, cyclopenta(c,d)pyrene (CPY), benz(a)anthracene (BaA), chrysene(+Triphenylene) (CHRY), 2,2-binaphtyl (BNT $(2,2))$, benzo(b)fluoranthene $(\mathrm{BbF})$, benzo(k)fluoranthene $(\mathrm{BkF})$, benzo(e)pyrene $(\mathrm{BeP})$, benzo(a)pyrene $(\mathrm{BaP})$, indeno (1,2,3-c,d)pyrene (IcdP), dibenz(a,h)anthracene (DahA), and benzo(g,h,i)perylene (BghiP), coronene (COR), 9H-Fluoreneone (FLO $(9 \mathrm{H})$ ), 9,10-Anthracenedione (ANT $(9,10)$ ) and 1,2-Benzanthraquinone (BAQ $(1,2)$ ). Four deuterated PAHs, (acenaphthene-d10, phenanthrene-d10, chrysene-d12, and perylene-d12) and two deuterated alkanes (tetracosane-d50 and tetratriacontane-d70) were used as internal standards, following the analytical method described by (Neusüss et al., 2000). For each analyzed compound, sample concentration was calculated by subtracting the average concentration of three blank filters from the measured concentration.

\subsection{Mass closure and diagnostic ratios}

$\mathrm{PM}_{2.5}$ main components were estimated from the concentrations of $\mathrm{EC}$, OC, water-soluble ions $\left(\mathrm{NO}_{3}{ }^{-}, \mathrm{SO}_{4}{ }^{2-}, \mathrm{NH}_{4}{ }^{+}\right.$and $\left.\mathrm{Na}^{+}\right)$ and tracer metal concentrations ( $\mathrm{Ca}, \mathrm{Ti}, \mathrm{Fe}, \mathrm{Ni}, \mathrm{Cu}, \mathrm{Zn}, \mathrm{As}, \mathrm{Se}, \mathrm{Sb}, \mathrm{Ba}$ and $\mathrm{Pb}$ ). The main components considered were organic material $(\mathrm{OM})$, elemental carbon (EC), ammonium sulfate $\left(\left(\mathrm{NH}_{4}\right)_{2} \mathrm{SO}_{4}\right)$, ammonium nitrate $\left(\mathrm{NH}_{4} \mathrm{NO}_{3}\right)$, crustal material (dust), other trace elements oxides (TEOs), particle-bounded water (PBW), and sea salt (SS), reckoned as sodium chloride. $\mathrm{PM}_{2.5}$ closure is described by Eq 1 (Dabek-Zlotorzynska et al., 2011). Except for EC, these components were not directly determined by chemical analysis but calculated from measured species. For these, we used the Interagency Monitoring of Protected Visual Environment (IMPROVE) equations (Chow et al., 2015). See Table 1. Also, this reconstruction was instrumental towards the identification of the main fine airborne particle sources.

The aerosol particle bounded water content was estimated from measured ionic composition, relative humidity, and temperature following the aerosol inorganic model (AIM) described by (Clegg et al., 1998), available for running online at http://www.aim.env.uea.ac.uk/aim/model2/model2a.php. AIM describes the thermodynamic equilibrium of the system $\mathrm{H}^{+}-$ $\mathrm{NH}_{4}{ }^{+}-\mathrm{SO}_{4}{ }^{2-}-\mathrm{NO}_{3}-\mathrm{H}_{2} \mathrm{O}$. 
206 Table 1. Equations used to estimate the main components of $\mathrm{PM}_{2.5}$

\begin{tabular}{|c|c|c|}
\hline $\begin{array}{l}\text { Component } \\
\text { OMprim }\end{array}$ & $\begin{array}{l}\text { Equation } \\
=f_{l} \mathrm{OC}_{\mathrm{prim}}\end{array}$ & $\begin{array}{l}\text { Reference } \\
\text { (Chow et al., 2015) } \\
\text { (Turpin and Lim, 2001) }\end{array}$ \\
\hline $\begin{array}{l}\mathrm{OM}_{\mathrm{sec}} \\
\left(\mathrm{NH}_{4}\right)_{2} \mathrm{SO}_{4} \\
\left(\mathrm{NH}_{4}\right) \mathrm{NO}_{3}\end{array}$ & $\begin{aligned}= & f_{2} \mathrm{OC}_{\mathrm{sec}} \\
= & 1.3754\left(\mathrm{SO}_{4}{ }^{2-}\right)_{\mathrm{nss}} \\
& \text { Where }\left(\mathrm{SO}_{4}{ }^{2-}\right)_{\mathrm{nss}}=\left(\mathrm{SO}_{4}{ }^{2-}\right)-0.252 \mathrm{Na}^{+} \\
= & 1.29\left(\mathrm{NO}_{3}^{-}\right)\end{aligned}$ & $\begin{array}{l}\text { (El-Zanan et al., 2005) } \\
\text { (Chow et al., 2015) }\end{array}$ \\
\hline SS & $=2.54\left(\mathrm{Na}^{+}\right)$ & $\begin{array}{l}\text { (Chow et al., 2015) } \\
\text { (Snider et al., 2016) }\end{array}$ \\
\hline Dust & $\begin{aligned}= & 1.63 \mathrm{Ca}+1.94 \mathrm{Ti}+2.42 \mathrm{Fe} \\
& \left(\text { Assuming } \mathrm{CaO}, \mathrm{Fe}_{2} \mathrm{O}_{3}, \mathrm{FeO} \text { (in equal amounts) and } \mathrm{TiO}_{2}\right)\end{aligned}$ & (Chow et al., 2015) \\
\hline PBW & $=k\left(\mathrm{SO}_{4}^{2-}+\mathrm{NH}_{4}^{+}\right)$ & (Clegg et al., 1998) \\
\hline TEO & $\begin{array}{l}=1.47[\mathrm{~V}]+1.27[\mathrm{Ni}]+1.25[\mathrm{Cu}]+1.24[\mathrm{Zn}]+1.32[\mathrm{As}]+ \\
1.2[\mathrm{Se}]+1.07[\mathrm{Ag}]+1.14[\mathrm{Cd}]+1.2[\mathrm{Sb}]+1.12[\mathrm{Ba}]+ \\
1.23[\mathrm{Ce}]+1.08[\mathrm{~Pb}]\end{array}$ & (Snider et al., 2016) \\
\hline
\end{tabular}

$f_{1}=1.6$. This factor was estimated considering the predominant sources.

$208 f_{2}=2.2$. This factor was estimated by subtracting the non-carbon component of $\mathrm{PM}_{2.5}$ from the measured mass.

$209 k=0.32$ was calculated using the Aerosol Inorganic Model.

The EC tracer method was applied to estimate primary $\left(\mathrm{OC}_{\mathrm{prim}}\right)$ and secondary $\left(\mathrm{OC}_{\mathrm{sec}}\right)$ organic carbon (Lee et al., 2010). This method utilizes EC as a tracer for primary OC, which implies that from non-combustible sources $\mathrm{OC}_{\text {prim }}$ is deemed negligible. Primary and secondary OC can be estimated upon defining a suitable primary OC to EC ratio ([OC/EC $]_{\text {prim}}$ ). See Eq (2) and $\mathrm{Eq}(3)$. We estimated the $[\mathrm{OC} / \mathrm{EC}]_{\text {prim }}$ ratio as the slope of a Deming linear fit between EC and OC measurements. The term $b$ corresponds to the linear fit intercept, which can be interpreted as the emitted $\mathrm{OC}_{\text {prim }}$ that is not associated with EC emissions. This method is limited by the following assumptions: 1) $[\mathrm{OC} / \mathrm{EC}]_{\text {prim }}$ is deemed constant, while in fact this ratio might change during the day according e.g. to the wind direction and the location of the dominant emission sources. Our 23-h sampling is expected to smooth this variability source out; 2) It neglects $\mathrm{OC}_{\text {prim }}$ from non-combustible sources; and 3) Assumes that $\mathrm{OC}_{\text {prim }}$ is nonvolatile and nonreactive. Departure from these assumptions implies that the estimation of $\mathrm{OC}_{\text {prim }}$ and $\mathrm{OC}_{\mathrm{sec}}$ might be biased, likely underestimating $\mathrm{OC}_{\text {sec. }}$.

$$
O C_{\text {prim }}=[O C / E C]_{\min } * E C+b \quad \text { Eq (2) }
$$

$$
O C_{\text {sec }}=O C-O C_{\text {prim }}
$$


As per Table 1, OM was estimated from OC using conversion factors $f_{1}$ and $f_{2}$ (Chow et al., 2015), which depend on the OM oxidation level and the secondary organic aerosol formation and aging during transport. Turpin and Lim, (2001a) recommended a ratio of 1.6 and 2.1 for urban and non-urban areas, respectively. However, biomass burning aerosols can have an even higher $f$ values (2.2-2.6), due to the presence of organic components with higher molecular weight, e.g., levoglucosan. We believe that traffic is the dominant $\mathrm{OC}_{\text {prim }}$ source at out site, therefore used an $f_{1}=1.6$ to estimate $\mathrm{OM}_{\text {pri }}$.

We used a factor of 2.2 to estimate $\mathrm{OM}_{\mathrm{sec}}$ from $\mathrm{OC}_{\mathrm{sec}}$ fraction. This factor was chosen based on i) recommended ratios of $2.1 \pm 0.2$ for aged or non-urban aerosols and ii) the molecular weight to carbon weight ratio for levoglucosan of 2.2. Levoglucosan is taken as component of reference due to its abundance in samples collected where the biomass burning happens often and as shown in section 3.6, levoglucosan was a tracer present in whole samples collected in this study (Schauer, 1998).

Concentration ratios among distinct species were used to chemically characterize and infer the main sources of fine particle matter at Palmira. $\mathrm{PM}_{2.5}$ acidity was assessed through cation and anion charge balances and then by comparison of cation equivalent (CE) and anion equivalent (AE) concentrations (Eq (4) and Eq (5)). Parent PAH ratios are widely used to identify combustion-derived PAH (Khedidji et al., 2020; Szabó et al., 2015; Tobiszewski and Namieśnik, 2012), although some of them are photochemically degraded in the atmosphere (Yunker et al., 2002). Additionally, n-alkanes are used as markers of fossil fuel or vegetation contributions to $\mathrm{PM}_{2.5}$. The parameters used to elucidate the $\mathrm{n}$-alkane origin were carbon number maximum concentration $\left(\mathrm{C}_{\max }\right)$, carbon preference index (CPI) and wax n-alkanes percentage (WNA\%). Table 2 summarizes the diagnostic ratio equations and the expected dominant source according to the ratio value.

$$
\begin{array}{ll}
A E=\frac{\left[\mathrm{SO}_{4}^{2-}\right]}{48}+\frac{\left[\mathrm{NO}_{3}^{-}\right]}{62}+\frac{\left[\mathrm{C}_{2} \mathrm{O}_{4}{ }^{2-}\right]}{44}+\frac{\left[\mathrm{Cl}^{-}\right]}{35}+\frac{\left[\mathrm{PO}_{4}^{3-}\right]}{31.3}+\frac{\left[\mathrm{NO}_{2}^{-}\right]}{46}+\frac{\left[\mathrm{Br}^{-}\right]}{79.9}+\frac{\left[\mathrm{F}^{-}\right]}{18.9}+\frac{\left[\mathrm{CH}_{3} \mathrm{O}_{3} \mathrm{~S}^{-}\right]}{95}+\frac{\left[\mathrm{CHO}_{2}^{-}\right]}{45} & \text { Eq (4) } \\
C E=\frac{\left[\mathrm{Na}^{+}\right]}{23}+\frac{\left[\mathrm{K}^{+}\right]}{39}+\frac{\left[\mathrm{NH}_{4}^{+}\right]}{18}+\frac{\left[\mathrm{Mg} \mathrm{g}^{2+}\right]}{12}+\frac{\left[\mathrm{Ca}^{2+}\right]}{20} & \text { Eq (5) }
\end{array}
$$


248 Table 2. Diagnostic ratios of organic compounds used to infer the sources of $\mathrm{PM}_{2.5}$ in this study.

\begin{tabular}{|c|c|c|c|c|}
\hline Diagnostic ratios & Equation & Value & Source & References \\
\hline $\mathrm{BeP} /(\mathrm{BeP}+\mathrm{BaP})$ & & $\begin{array}{l}\sim 0.5 \\
<0.5\end{array}$ & $\begin{array}{l}\text { Fresh particles } \\
\text { Photolysis }\end{array}$ & $\begin{array}{l}\text { (Tobiszewski and } \\
\text { Namieśnik, 2012) }\end{array}$ \\
\hline IcdP/(IcdP+BghiP) & & $\begin{array}{l}\quad<0.2 \\
0.2-0.5 \\
>0.5\end{array}$ & $\begin{array}{l}\text { Petrogenic } \\
\text { Petroleum combustion } \\
\text { Grass, wood and coal } \\
\text { combustion }\end{array}$ & $\begin{array}{l}\text { (Yunker et al., 2002) } \\
\text { (Tobiszewski and } \\
\text { Namieśnik, 2012) }\end{array}$ \\
\hline & & $<0.6$ & Non-traffic emissions & (Tobiszewski and \\
\hline BaP/BghiP & & $>0.6$ & Traffic emissions & $\begin{array}{c}\text { Namieśnik, 2012) (Szabó } \\
\text { et al., 2015) }\end{array}$ \\
\hline IcdP/BghiP & & $\begin{array}{l}>1.25 \\
<0.4\end{array}$ & $\begin{array}{l}\text { Brown coal* } \\
\text { Gasoline }\end{array}$ & (Ravindra et al., 2008) \\
\hline LMW/(MMW+HMW) & & $\begin{array}{l}<1 \\
>1\end{array}$ & $\begin{array}{l}\text { Pyrogenic } \\
\text { Petrogenic }\end{array}$ & $\begin{array}{l}\text { (Tobiszewski and } \\
\text { Namieśnik, 2012) }\end{array}$ \\
\hline $\mathrm{C}_{\max }$ & & $\begin{array}{c}<\mathrm{C}_{25} \\
\mathrm{C}_{27}-\mathrm{C}_{34}\end{array}$ & $\begin{array}{l}\text { Anthropogenic } \\
\text { Vegetative detritus }\end{array}$ & (Lin et al., 2010) \\
\hline CPI & $C P I=0.5 *\left[\frac{\sum_{19}^{33} C_{i}}{\sum_{20}^{32} C_{k}}+\frac{\sum_{19}^{33} C_{i}}{\sum_{22}^{34} C_{k}}\right]$ & $\begin{array}{l}\mathrm{CPI} \sim 1 \\
\mathrm{CPI}>1\end{array}$ & $\begin{array}{l}\text { Fossil carbon } \\
\text { Biogenic }\end{array}$ & $\begin{array}{l}\text { (Marzi et al., 1993) } \\
\text { (Kang et al., 2018) }\end{array}$ \\
\hline WNA\% & $\begin{array}{c}\sum W N A_{C_{n}}=\left[C_{n}\right]-\left[\frac{\left(C_{n+1}\right)+\left(C_{n-1}\right)}{2}\right] \\
W N A \%=\frac{\sum W N A_{C_{n}}}{\sum \text { Total } n-\text { alkanes }} \\
P N A \%=100-W N A \%\end{array}$ & $\begin{array}{l}\text { WNA } \sim 100 \\
\text { PNA } \sim 100\end{array}$ & $\begin{array}{c}\text { Biogenic } \\
\text { Anthropogenic }\end{array}$ & (Lyu et al., 2019) \\
\hline
\end{tabular}

*Used for residential heating and industrial operation.

As all the measured variables were subject to analytical uncertainty and temporal variability, linear fitting parameters were obtained from Deming regressions as recommend for atmospheric measurements (Wu and Zhen Yu, 2018). The Spearman coefficient was selected as an indicator of statistical correlation between chemical components instead of Pearson's to reduce the effect of outliers. Derived ratios and other parameters were considered statistically significant when p-values $<0.05$. The statistical analysis was made using $\mathrm{R}$ version 4.0.2, 24 including the packages corrr (0.4.2), mcr (1.2.1), cluster (2.1.0), tidyverse (1.3.0), ggplot (3.3.2), psych (2.0.9) and openair (2.7-4).

\subsection{Principal component analysis (PCA)}

259 There is very little information in the literature on the composition of several of the aerosol emission sources deemed important 260 in CRV. This is particularly true for sugarcane pre-harvest burning and sugarcane bagasse combustion. Because of this, instead of directly jumping into a source attribution effort, using receptor modeling methods, we deemed it more important at this 
stage of our research to apply multivariate statistical techniques to unravel correlations among the various aerosol components, and to potentially identify various aerosol sources. For this, we applied principal component analysis (PCA). We consider this useful in our case, even if PCA is nowadays considered an outdated technique for source attribution in regions with reasonably characterized sources (Hopke, 2016). The species $\mathrm{Br}^{-}, \mathrm{C}_{19} \mathrm{H}_{40}$, $\mathrm{COR}$, and manosan were excluded from these analyses because more than $80 \%$ of their concentrations were below the detection limit (BDL). Data were organized into a matrix of $45 \mathrm{PM}_{2.5}$ samples (rows) times 73 chemical species (columns). BDL "missing” values were replaced by corresponding species detection limit. To reduce skewness and order of magnitude effects, the concentration dataset was log10-transformed, mean-centered, and scaled to unit variance. Principal components were derived from the correlation matrix. We applied varimax rotation PCA as rotated components have easier-to-interpret loadings. Principal components (PC) were selected to explain at least $60 \%$ of the total variance. Calculations were made with the Psych (2.0.9) R package.

\section{Results and discussions}

\subsection{Meteorology}

The Andes Cordillera splits into three south-to-north diverging mountain ranges (Western, Central, and Eastern Cordilleras) near the Colombia-Ecuador border. The Cauca River Valley (CRV) is an inter-Andean valley at $\sim 985 \mathrm{~m}$ altitude located $\sim 120$ $\mathrm{km}$ from the Pacific Ocean, bounded by the Central and Western Cordilleras (see Figure 1). The Western Cordillera separates CRV from the Colombian Pacific Ocean watershed, the rainiest region on Earth (Rojo H. and Mesa O., 2020). The elevated precipitation in this basin is due to the presence of a Walker cell convergence zone at surface, persistent under neutral and La Niña conditions. This synoptic feature is one the most important determinants of atmospheric circulation in Colombia, with prevailing east-to-west winds in the lower troposphere along with upper troposphere return winds (Mesa S. and Rojo H., 2020). The Andean Cordilleras are nevertheless effective barriers to the Walker circulation near the CRV surface (Lopez and Howell, 1967). The elevated humidity in the Pacific Ocean watershed and the closeness of the two Andes branches drive a zonal regional circulation pattern, consisting in west-to-east anabatic winds over the Pacific slope of the Western Cordillera during daytime followed by rapid katabatic winds late afternoon (Lopez and Howell, 1967). These winds rapidly ventilate CRV during the late afternoon - early evening period on an almost regular basis. CRV is wide $(\sim 22 \mathrm{~km})$ and long $(\sim 248 \mathrm{~km})$ enough to develop a valley-mountain wind circulation pattern during daytime. Winds are very mild during this time period and expectedly highly dispersive, i.e. with high turbulence intensities (Ortiz et al., 2019). The arrival of the katabatic "tide" at late afternoon wipes the valley-mountain wind pattern out.

One year prior to the sampling period, we monitored the local meteorology, first at $14.5 \mathrm{~m}$, a few meters over the mean canopy level, and then at $32.5 \mathrm{~m}$ during the sampling campaign. The box-and-whisker plot in Fig 2 shows katabatic tide winds of up to $\sim 8 \mathrm{~m} / \mathrm{s}$ at the sampling site elevation, peaking at $\sim 17: 00 \mathrm{LT}$. Wind speeds were a factor $\sim 2-3$ slower at ground level. The wind runs at the sampling height were typically over $\sim 200 \mathrm{~km}$ per day (Fig S3) indicating that the samples had quite a large 
spatial coverage of CRV, much larger than it would have been at ground level. This also implies that the samples were frequently and significantly influenced by emissions coming from Yumbo's industrial hub (northwest of Palmira), and also by Palmira and Yumbo urban and highway emissions, along with pre-harvest sugarcane burning and sugarcane mill emissions. The wind rose (Fig 2a) suggests that the influence of urban emissions from Cali, CRV's largest city by far, was minor. Other meteorological variables are reported in the Supplementary Material (SM) (Fig S2). Temperature $\left(24.2^{\circ} \mathrm{C}\right.$ on average) and relative humidity $(71.6 \%)$ were very likely controlled by solar radiation $\left(350 \mathrm{~W} \mathrm{~m}^{-2}\right.$ on average). The pressure daily profile ( $763 \mathrm{hPa}$ on average) clearly showed the influence of the katabatic tide, with a $\sim 3 \mathrm{hPa}$ drop during its arrival at late afternoon.

Overall, we believe our measurements at the Palmira site are quite representative of the regional air quality.

a

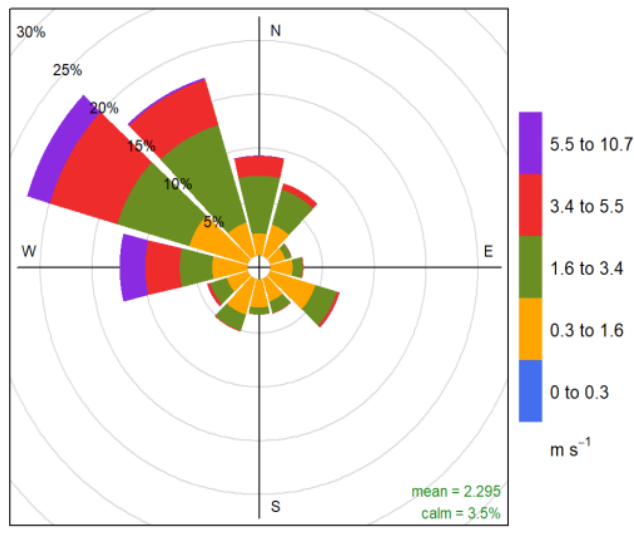

Frequency of counts by wind direction (\%) $\mathrm{b}$

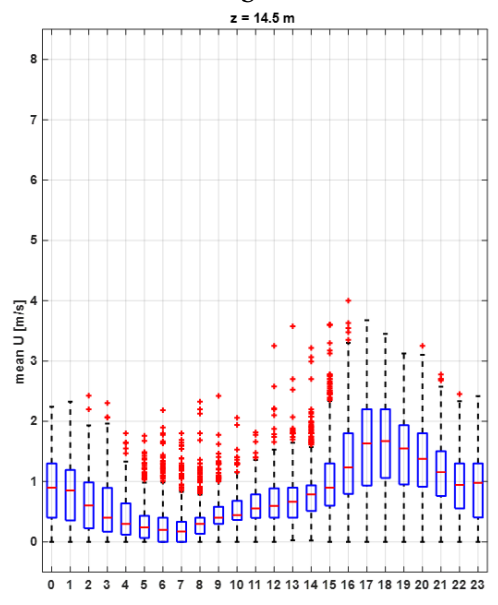

$\mathrm{c}$

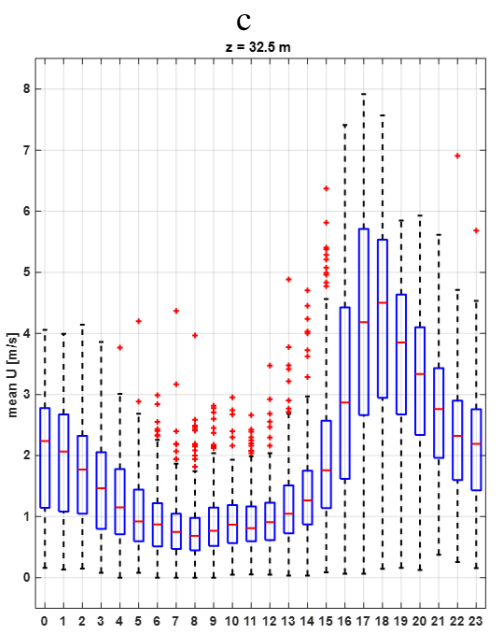

302

303

304

305

306

307

308

309 310

Figure 2. Wind pattern in the sampling location: a) predominant wind rose during sampling period, b) hourly profile of wind speed to $14.5 \mathrm{~m}$ over ground level and c) hourly profile of wind speed in sampling location at $32.5 \mathrm{~m}$ over the ground level.

\subsection{Bulk PM 2.5 concentration and composition}

The daily $\mathrm{PM}_{2.5}$ concentration measured in this study ranged from 6.73 to $24.45 \mu \mathrm{g} \mathrm{m}^{-3}$ with a campaign average of $14.38 \pm$ $4.35 \mathrm{\mu g} \mathrm{m}^{-3}$ (23 h-average, \pm 1 -sigma). Although these concentrations may appear comparatively low, it is worth stressing that samples were collected at more than $30 \mathrm{~m}$ height with hourly wind speeds frequently above $4 \mathrm{~m} \mathrm{~s}^{-1}$.

Previous studies conducted in rural areas of Brazil impacted by open field sugarcane burning reported significantly higher (mean $22.7 \mu \mathrm{g} \mathrm{m}^{-3}$; Lara et al., 2005), similar (mean $18 \mu \mathrm{g} \mathrm{m}^{-3}$ Souza et al., 2014), and significantly lower $\mathrm{PM}_{2.5}$ concentrations (mean $10.88 \mathrm{\mu g} \mathrm{m}^{-3}$; Franzin et al., 2020). Comparable measurements in Mexico during harvest periods showed much higher concentrations, from $29.14 \mu \mathrm{g} \mathrm{m}^{-3}$ (Mugica-Alvarez et al., 2015) up to $51.3 \mu \mathrm{g} \mathrm{m}^{-3}$ (Mugica-Álvarez et al., 2016). Our $\mathrm{PM}_{2.5}$ concentration measurements in CRV are thus substantially lower than those usually reported in Mexico and Brazil during 

Mexico must be considered while comparing concentrations. First, currently in CRV, "just" $\sim 1 / 3$ of the sugarcane area is burned before harvesting compared to much larger fractions in Mexico and Brazil. Second, sugarcane is harvested year-long in CRV compared to Brazil and Mexico, where harvest is limited to a 6-month period (known as zafra in Spanish, "the harvest"). Third, the size of the individual plots burned in CRV is typically $\sim 6$ ha (median burned area; Cardozo-Valencia et al., 2019), compared to much larger plots and total areas in Brazil and Mexico.

OC was the most abundant measured component of $\mathrm{PM}_{2.5}$ with a mean daily concentration of $3.97 \pm 1.31 \mu \mathrm{g} \mathrm{m}^{-3}$, whereas the mean EC concentration was only $0.96 \pm 0.31 \mu \mathrm{g} \mathrm{m}^{-3}$. These two contributed to $29.1 \pm 8.3 \%$ and $7.2 \pm 2.3 \%$ of the $\mathrm{PM}_{2.5}$ mass, respectively (carbonaceous fractions were thus $4.93 \pm 1.58 \mu \mathrm{g} \mathrm{m}^{-3}$, i.e. $36.31 \pm 10.41 \%$ of $\mathrm{PM}_{2.5}$ ). The most abundant watersoluble ions found in Palmira's $\mathrm{PM}_{2.5}$ were $\mathrm{SO}_{4}{ }^{2-}, \mathrm{NH}_{4}{ }^{+}$, and $\mathrm{NO}_{3}$, with average concentrations of $2.15 \pm 1.39 \mu \mathrm{g} \mathrm{m}{ }^{-3}, 0.67 \pm$ $0.62 \mu \mathrm{g} \mathrm{m}^{-3}$, and $0.51 \pm 0.30 \mu \mathrm{g} \mathrm{m}^{-3}$, respectively $(12.7 \pm 2.8 \%, 3.7 \pm 1.1 \%$ and $2.6 \pm 1.3 \%$ of mass concentration, respectively). Mean concentrations of other water-soluble ions, such as $\mathrm{Na}^{+}, \mathrm{Ca}^{+}$, and $\mathrm{C}_{2} \mathrm{O}_{4}{ }^{2-}$, were around $0.1 \mu \mathrm{g} \mathrm{m}{ }^{-3}$, while those of $\mathrm{K}^{+}$, $\mathrm{PO}_{4}{ }^{3-}, \mathrm{CH}_{3} \mathrm{O}_{3} \mathrm{~S}^{-}, \mathrm{Mg}^{2+}$, and $\mathrm{Cl}^{-}$ranged within 10-80 $\mathrm{ng} \mathrm{m}^{-3}$ (Table 3).

The predominant elements were $\mathrm{Ca}\left(0.42 \pm 0.33 \mu \mathrm{g} \mathrm{m}^{-3}\right), \mathrm{K}\left(0.13 \pm 0.08 \mu \mathrm{g} \mathrm{m}^{-3}\right)$, and $\mathrm{Fe}\left(88 \pm 65 \mathrm{ng} \mathrm{m}^{-3}\right)$, followed by $\mathrm{Zn}(34$ $\left.\pm 33 \mathrm{ng} \mathrm{m}^{-3}\right), \mathrm{Pb}\left(18 \pm 19 \mathrm{ng} \mathrm{m}^{-3}\right), \mathrm{Sn}\left(52 \pm 37 \mathrm{ng} \mathrm{m}^{-3}\right), \mathrm{Ti}\left(5 \pm 4 \mathrm{ng} \mathrm{m}^{-3}\right), \mathrm{Ba}\left(9 \pm 13 \mathrm{ng} \mathrm{m}^{-3}\right), \mathrm{Sr}\left(2 \pm 5 \mathrm{ng} \mathrm{m}^{-3}\right) . \mathrm{Mn}, \mathrm{Ni}, \mathrm{Cr}$, and Se concentrations were below $2 \pm 1 \mathrm{ng} \mathrm{m}^{-3}$. Tracer metals such as $\mathrm{Ti}, \mathrm{Cr}, \mathrm{Mn}, \mathrm{K}, \mathrm{Ca}, \mathrm{Fe}, \mathrm{Ni}, \mathrm{Cu}, \mathrm{Zn} \mathrm{Sr}, \mathrm{Pb}$ and $\mathrm{Se}$ were found in all $\mathrm{PM}_{2.5}$ samples, while $\mathrm{V}$ was not found in any sample. Other tracer metals such as As and Sb were detected only at a reduced number of samples with concentrations below $20 \mathrm{ng} \mathrm{m}^{-3}$. Table 3 shows the mean, standard deviation, minimum and maximum concentration of the carbonaceous fraction, soluble ions, and metals found in the $\mathrm{PM}_{2.5}$ samples collected in CRV. 
https://doi.org/10.5194/acp-2021-601

Preprint. Discussion started: 3 August 2021

(c) Author(s) 2021. CC BY 4.0 License.

347 Table 3. Mean, 1 standard deviation, minimum and maximum concentrations of carbonaceous fraction, soluble ions, and 348 metals in samples of $\mathrm{PM}_{2.5}$ collected in Palmira.

\begin{tabular}{|c|c|c|c|c|c|}
\hline Species & Mean & SD & Min & Max & Units \\
\hline $\mathrm{PM}_{2.5}$ & 14.38 & 4.35 & 6.73 & 24.45 & $\mu \mathrm{g} \mathrm{m}^{-3}$ \\
\hline $\mathrm{OC}$ & 3.97 & 1.31 & 2.31 & 8.35 & \\
\hline EC & 0.96 & 0.31 & 0.52 & 2.15 & \\
\hline $\mathrm{SO}_{4}^{-2}$ & 2.15 & 1.39 & 0.98 & 10.27 & \\
\hline $\mathrm{NH}_{4}^{+}$ & 0.67 & 0.62 & 0.18 & 4.29 & \\
\hline $\mathrm{NO}_{3}^{-}$ & 0.51 & 0.30 & 0.11 & 1.45 & \\
\hline $\mathrm{Na}^{+}$ & 0.21 & 0.16 & 0.02 & 0.45 & \\
\hline $\mathrm{Ca}^{+2} \quad$ (Water soluble ion) & 0.14 & 0.06 & 0.06 & 0.28 & \\
\hline $\mathrm{C}_{2} \mathrm{O}_{4}^{-2}$ & 0.11 & 0.06 & 0.04 & 0.36 & \\
\hline $\mathrm{K}^{+} \quad$ (Water soluble ion) & 0.09 & 0.06 & 0.02 & 0.30 & \\
\hline (Trace metal) & 0.42 & 0.33 & 0.01 & 1.95 & \\
\hline (Trace metal) & 0.13 & 0.08 & 0.02 & 0.46 & \\
\hline Formate & 82 & 88 & 0 & 217 & $\mathrm{ng} \mathrm{m}^{-3}$ \\
\hline $\mathrm{PO}_{4}^{-3}$ & 66 & 42 & 10 & 148 & \\
\hline Methansulfonate & 50 & 36 & 13 & 256 & \\
\hline $\mathrm{Cl}-$ & 20 & 19 & 0 & 75 & \\
\hline $\mathrm{Mg}^{+2}$ & 19 & 10 & 2 & 52 & \\
\hline $\mathrm{NO}_{2}^{-}$ & 3 & 1 & 1 & 6 & \\
\hline $\mathrm{Fe}$ & 88 & 64 & 2 & 293 & \\
\hline Sn & 52 & 37 & 9 & 137 & \\
\hline $\mathrm{Zn}$ & 34 & 33 & 0 & 153 & \\
\hline $\mathrm{Pb}$ & 18 & 19 & 0 & 84 & \\
\hline $\mathrm{Ba}$ & 9 & 13 & 2 & 72 & \\
\hline $\mathrm{Sb}$ & 8 & 5 & 3 & 22 & \\
\hline $\mathrm{Cu}$ & 6 & 5 & 1 & 22 & \\
\hline $\mathrm{Ti}$ & 5 & 4 & 0 & 17 & \\
\hline As & 2 & 4 & 0 & 10 & \\
\hline $\mathrm{Mn}$ & 2 & 1 & 0 & 5 & \\
\hline $\mathrm{Ni}$ & 2 & 1 & 0 & 9 & \\
\hline $\mathrm{Sr}$ & 2 & 5 & 0 & 28 & \\
\hline $\mathrm{Cr}$ & 1 & 1 & 0 & 4 & \\
\hline $\mathrm{Se}$ & 1 & 1 & 0 & 6 & \\
\hline $\mathrm{V}$ & 0 & 1 & 0 & 3 & \\
\hline
\end{tabular}




\subsection{PM2.5 mass closure}

The mass closure (Figure 3) shows the crucial contribution of organic material $(52.99 \% \pm 17.79 \%)$ and the secondary inorganic fraction, represented by ammoniated sulphate $(16.12 \pm 3.98 \%)$ and ammonium nitrate $(3.19 \pm 1.71 \%)$. EC constituted $6.95 \pm$ $2.52 \%$ of $\mathrm{PM}_{2.5}$. The mineral fraction corresponded to dust $(8.67 \pm 5.71 \%)$ and TEO $(0.82 \pm 0.44 \%)$. The sea salt was $0.80 \pm$ $1.28 \%$ and PBW $5.20 \pm 1.20 \%$. A mass closure of $93.40 \pm 33.38 \%$ was achieved. Although the $\mathrm{PM}_{2.5}$ concentrations observed in the CRV were not so high as compared with those registered in Brazil and Mexico during the preharvest season, the EC percentage is in a similar range or slightly lower than those observed in other urban areas (Snider et al., 2016), showing the key role of incomplete combustion processes in the area.

The average (OC/EC) ratio found in CRV was $4.2 \pm 0.72$, from which we can infer that secondary aerosol formation had a relevant role. The segregation of OC in the primary and secondary fraction was made using the EC tracer method applied in previous studies (Pio et al., 2011; Plaza et al., 2011). The (OC/EC) $\min$ ratio selected to differentiate $\mathrm{OC}_{\text {prim }}$ from $\mathrm{OC}_{\text {sec }}$ was the minimum ratio observed, equivalent to 2.12. Still, this value could induce the overestimation of $\mathrm{OC}_{\text {prim }}$ due to the distance between the emission sources and the sampling site ( $27 \mathrm{~m}$ overground), and by the local meteorological conditions that favor the volatilization and oxidation of organic components into particles before being collected. As result, $\mathrm{OC}_{\text {prim }}$ was estimated as $50.3 \%$ and $\mathrm{OC}_{\mathrm{sec}}$ as $49.7 \%$ over the total $\mathrm{OC}$, with a minimum variability of $3.8 \%$. The estimated $\mathrm{OM}_{\text {pri }}$ concentration was $2.95 \pm 1.05 \mu \mathrm{g} \mathrm{m}^{-3}$ and the $\mathrm{OM}_{\mathrm{sec}}$ concentration was $4.08 \pm 1.86 \mu \mathrm{g} \mathrm{m}^{-3}$ that represented the 24.4 and 31.0 of $\mathrm{PM}_{2.5}$ respectively.

The mineral fraction, quantified as the sum of the oxides present in the crustal material (dust) and other trace element oxides (TEO) contributed $9.1 \pm 5.5 \%$ and $0.9 \pm 0.4 \%$, respectively. Despite the non-quantification of highly abundant mineral dust elements such as $\mathrm{Si}$, the concentrations of $\mathrm{Ca}$, $\mathrm{Ti}$, and $\mathrm{Fe}$ indicated the impact of soil resuspension on the $\mathrm{PM}_{2.5} \mathrm{mass}$ concentration.

Particle-bound water (PBW) depends on the concentration of hygroscopic compounds embodied in the particulate matter and relative humidity of the weighing room where the $\mathrm{PM}_{2.5}$ mass collected on the filters was determined. In this study, it was assumed that (i) $\mathrm{NH}_{4}{ }^{+}, \mathrm{SO}_{4}{ }^{2-}$ and $\mathrm{NO}_{3}{ }^{-}$were the main compounds responsible for the absorbed water and (ii) thermodynamic equilibrium is dominated by these ions that allow calculating the $\mathrm{H}^{+}$molar fraction as a difference of $\left(\mathrm{SO}_{4}{ }^{2-}+\mathrm{NO}_{3}{ }^{-}\right)$and $\mathrm{NH}_{4}{ }^{+}$ required to establish the charge neutrality. Polar organic compounds and other water-soluble ions were not considered in the present study. The PBW content was estimated using the mean measured concentrations of $\mathrm{NH}_{4}{ }^{+}, \mathrm{SO}_{4}{ }^{2-}$ and $\mathrm{NO}_{3}{ }^{-}$in the AIM Model, where a multiplier factor was found equivalent to 0.32 as a proportion between the concentrations of summatory of theses ions and the water fraction contained in the $\mathrm{PM}_{2.5}$. As a result, the PBW was 5.3\% of $\mathrm{PM}_{2.5}$ mass concentration. 


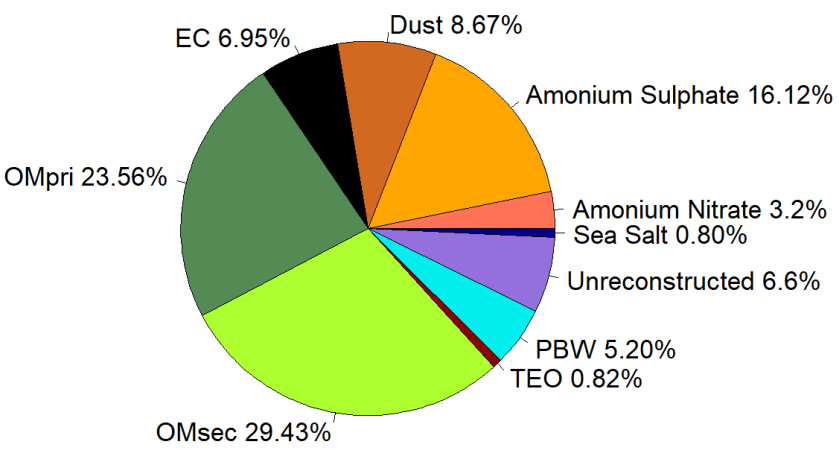

Figure 3. Mean fractions of $\mathrm{PM}_{2.5}$ components of in the CRV.

\subsection{Ions}

Anion- and cation-equivalent ( $\mathrm{AE}$ and $\mathrm{CE}$, respectively) charges were compared to estimate the acidity of $\mathrm{PM}_{2.5}$ (Figure 4). $\mathrm{AE}$ and $\mathrm{CE}$ displayed a tight Spearman linear correlation $\left(\mathrm{r}^{2}=0.99\right)$. The $\mathrm{AE}$ to $\mathrm{CE}$ ratio of $1.2 \pm 0.1$ suggests that cations were generally well balanced by anions and that $\mathrm{PM}_{2.5}$ was nearly neutral. Just a few samples displayed AE/CE ratios significantly higher than 1, i.e. slightly acidic, which might be attributed to the sulfate dianion $\left(\mathrm{SO}_{4}{ }^{2-}\right)$ abundance. The ratio between the two main water-soluble ions, ammonium cation $\left(\mathrm{NH}_{4}{ }^{+}\right)$and $\mathrm{SO}_{4}{ }^{2-}$, was $\left[\mathrm{NH}_{4}{ }^{+}\right] /\left[\mathrm{SO}_{4}{ }^{2-}\right]=0.3 \pm 0.1$ This indicates that fine PM in CRV is more acidic than suggested by the AE/CE ratio. This acidity might be explained by insufficient ammonium in CRV's atmosphere to neutralize $\mathrm{SO}_{4}{ }^{2-}$ present in fine particulate matter.

Sulfate to nitrate ratios $\left(\left[\mathrm{SO}_{4}{ }^{2-}\right] /\left[\mathrm{NO}_{3}{ }^{-}\right]\right)$have been used as indicators of the relative contribution of mobile and stationary sources to particulate matter nitrogen and sulfur (Agarwal et al., 2020; Begam et al., 2016). High ratio values indicate dominance of stationary sources over vehicular emissions. The measured average ratio of $\left[\mathrm{SO}_{4}{ }^{2-}\right] /\left[\mathrm{NO}_{3}{ }^{-}\right]=4.5 \pm 2.9$ indicates that stationary sources are predominant in CRV. This ratio is higher than the one reckoned from measurements in Brazil by Souza et al. (2014) at Piracicaba (3.6 \pm 1.0$)$ and Sao Paulo $(1.8 \pm 1.0)$. The strong correlations between $\mathrm{SO}_{4}{ }^{2-}$ and $\mathrm{NH}_{4}{ }^{+}\left(\mathrm{r}^{2}=\right.$ $0.84), \mathrm{SO}_{4}{ }^{2-}$ and methanesulfonic acid $\left(\mathrm{CH}_{3} \mathrm{O}_{3} \mathrm{~S}^{-}\right)\left(\mathrm{r}^{2}=0.47\right)$, and $\mathrm{SO}_{4}{ }^{2-}$ and oxalate dianion $\left(\mathrm{C}_{2} \mathrm{O}_{4}{ }^{2-}\right)\left(\mathrm{r}^{2}=0.57\right)$ allows to infer that inorganic secondary aerosol formation is a significant $\mathrm{PM}_{2.5}$ source in CRV. In addition, the presence of potassium cation $\left(\mathrm{K}^{+}\right)$in submicron particles is recognized as a biomass burning tracer (Andreae, 1983; Ryu et al., 2004). $\mathrm{K}^{+}$showed a moderate correlation with nitrite anion $\left(\mathrm{NO}_{2}^{-}\right)\left(\mathrm{r}^{2}=0.56\right)$ and $\mathrm{C}_{2} \mathrm{O}_{4}{ }^{2-}\left(\mathrm{r}^{2}=0.54\right)$ in $\mathrm{CRV}$, which suggests that biomass burning influences secondary aerosol formation. $\mathrm{Mg}^{2+}$ and $\mathrm{Ca}^{2+}$ ions, usually considered crustal metals, exhibited a moderate correlation of $\mathrm{r}^{2}=$ 0.59 ( $\mathrm{Li}$ et al., 2013). Also, $\mathrm{Mg}^{2+}$ and $\mathrm{C}_{2} \mathrm{O}_{4}{ }^{2-}$ moderate correlation $\left(\mathrm{r}^{2}=0.42\right)$ points to a link among crustal species and secondary aerosols. Such an association could be plausibly explained by soil erosion induced by pyro-convection during sugarcane pre-harvest burning (Wagner et al., 2018). Our study full species correlation matrix is shown in Fig 3S. 


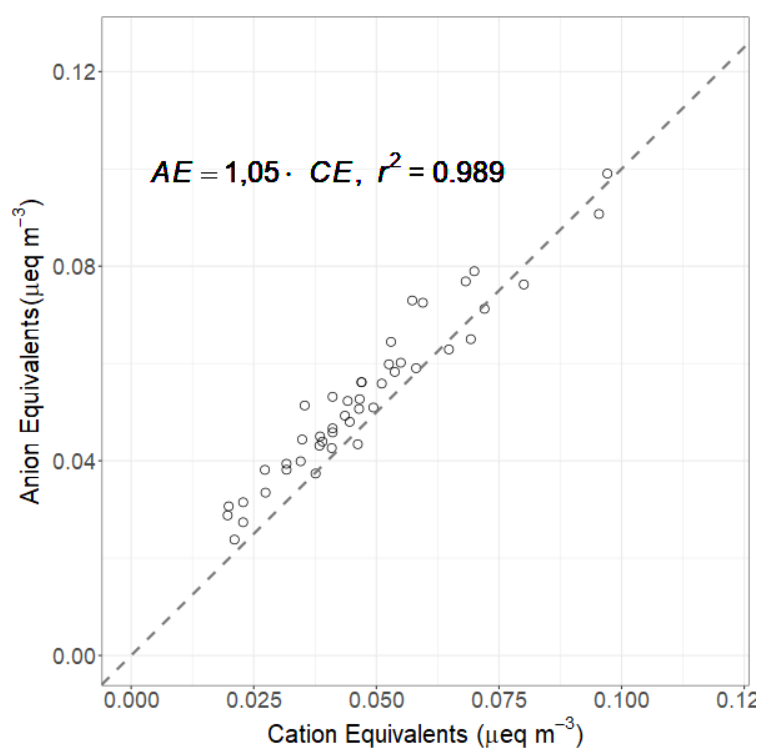

Figure 4. Scatter plot of the equivalent cations and anions for $\mathrm{PM}_{2.5}$ samples collected in Palmira.

\section{3.5. Metals}

The measured total $\mathrm{PM}_{2.5}$ trace metal concentration was $706 \pm 462 \mathrm{ng} \mathrm{m}^{-3}\left(101.3 \mathrm{ng} \mathrm{m}^{-3}\right.$ to $\left.2638 \mathrm{ng} \mathrm{m}^{-3}\right)$. Trace metals can originate from non-exhaust and exhaust emissions. The non-exhaust emissions come from brake and tire wear, road surface abrasion, wear/corrosion of other vehicle components, and resuspension of road surface dust. Exhaust emissions metals are related to fuel, lubricant combustion, catalytic converters, and engine corrosion. As shown by Kundu and Stone (2014), many of these sources share some metals in their chemical composition profile, , thus an unambiguous specific source attribution is non-trivial. In this study, we found a significant correlation among $\mathrm{Fe}, \mathrm{Mn}$ and $\mathrm{Ti}\left(\mathrm{r}^{2} \approx 0.72\right)$, which is typically associated with high abundance of crustal material (Fomba et al., 2018), and substantiates the importance of soil dust as a significant source in CRV. Also, tire and brake wear tracer metals, including $\mathrm{Zn}$ and $\mathrm{Cu}$, showed weaker but still significant correlations among them $\left(\mathrm{r}^{2} \approx 0.32\right) . \mathrm{PM}_{2.5} \mathrm{Ca}$ concentrations at Palmira were quite high $\left(405 \pm 334 \mathrm{ng} \mathrm{m}^{-3}\left(1.6 \mathrm{ng} \mathrm{m}^{-3}\right.\right.$ to $\left.1952 \mathrm{ng} \mathrm{m}^{-3}\right)$. These levels can be attributed to dust generation by agricultural practices, particularly land planning, liming and tilling, PHB pyro-convection induced soil erosion, and traffic-induced soil resuspension on unpaved rural roads. One of the very few previous investigations on PM composition in CRV (Criollo and Daza, 2011) analyzed trace metals in PM10 at 4 CRV locations, including Palmira. They found significant enrichment of Fe and $\mathrm{K}$ metals at locations exposed to PHB. It must be bear in mind that $\mathrm{PM}_{10}$ samples included coarse mode aerosols, of which dust might have been a significant fraction. Also, environmental regulations have been successful in steadily reducing the sugarcane burned area in CRV since 2009. Burned area dropped from 

Measured concentrations of $\mathrm{Pb}$ and $\mathrm{Ni}$ in $\mathrm{PM}_{2.5}$ at Palmira were $18 \mathrm{ng} \mathrm{m}^{-3}$ (+/-19) and $2 \mathrm{ng} \mathrm{m}^{-3}$ (+/-1), respectively. These mean values were below the EU target value $\left(0.5 \mu \mathrm{g} \mathrm{m}^{-3}\right.$ and $20 \mathrm{ng} \mathrm{m}^{-3}$ respectively) (WHO, 2013a), and below the allowed annual limit of the Colombian national air quality standard $\left(0.5 \mu \mathrm{g} \mathrm{m}^{-3}\right.$ and $0.18 \mu \mathrm{g} \mathrm{m}^{-3}$ respectively) (MADS, 2017). These concentrations are nevertheless significantly higher than those reported for other suburban areas in Midwestern United States and remote sites in northern tropical Atlantic (Fomba et al., 2018; Kundu and Stone, 2014). Pb concentrations are similar to those reported for Bogota and other large urban areas (SDA, 2010; Vasconcellos et al., 2007). Pb has been long banned as fuel additive in Colombia thus the observed levels might be associated with metallurgical industry and waste incineration. Information on ambient air hazardous metal concentration in Latin America urban and rural areas is still scarce.

\subsection{Carbohydrates}

Levoglucosan is a highly specific biomass burning organic tracer. Along with $\mathrm{K}^{+}$, OC and EC, it can be used to effectively identify the relevance of biomass burning as aerosol source. The relative contribution of levoglucosan to the particulate matter carbohydrate burden, and specially the levoglucosan to mannosan ratio, can be used as indicators of type of biomass burned (Engling et al., 2009). In this study, the following carbohydrates were quantified: levoglucosan, mannosan, glucose, galactosan, fructose and arabitol. Levoglucosan was by far the most abundant $\left(113.8 \pm 147.2 \mathrm{ng} \mathrm{m}^{-3}\right)$, reaching values of up to $904.3 \mathrm{ng}$ $\mathrm{m}^{-3}$, followed by glucose $\left(10.4 \pm 6.1 \mathrm{ng} \mathrm{m}^{-3}\right)$, mannosan $\left(7 \pm 6.1 \mathrm{ng} \mathrm{m}^{-3}\right)$, and arabitol $\left(4.1 \pm 3.5 \mathrm{ng} \mathrm{m}^{-3}\right)$. Levoglucosan and

The levoglucosan concentration found in this study was quite similar to the reported in areas of Brazil where sugarcane production and processing are important economic activities. For instance, during the harvest (zafra) period in Araraquara, the levoglucosan mean concentration was $138 \pm 91 \mathrm{ng} \mathrm{m}^{-3}$, although during the non-harvest period was unexpectly high (73 \pm 37 $\mathrm{ng} \mathrm{m}^{-3}$ ) (Urban et al., 2014). Likewise, the levoglucosan average concentration at Piracicaba during a reduced fire period was $66 \mathrm{ng} \mathrm{m}^{-3}$ (Souza et al., 2014). The measured mean levoglucosan/mannosan ratio in Palmira was $17.6 \pm 13.0$ (min: 8.1 - max: 58.1). Chemical profile studies found a levoglucosan/manossan ratio of $\sim 10$ for sugarcane leaves burned in stoves (Hall et al., 2012; Dos Santos et al., 2002) and of $~ 54$ for burned bagasse (Dos Santos et al., 2002). Leaves constitute the largest fraction (20.8\%, Victoria et al., 2002) of pre-harvest burned sugarcane. Consistently and expectedly, the levoglucosan/mannosan ratio at Palmira is much closer to the chemical profile ratio of leaves than that of bagasse. Moreover, ambient air samples in Araraquara and Piracicaba showed levoglucosan/mannosan ratios of $9 \pm 5$ and $\sim 33$, respectively. For comparison, the levoglucosan/mannosan ratio in particulate matter from rice straw and other crops burning were $\sim 26.6$ and 23.8 , respectively (Engling et al., 2009). This indicates that the levoglucosan/manossan ratio is sensitive to the type of biomass burned but also 
to burning conditions. The large levoglucosan/mannosan ratio variability in our study suggest that Palmira was impacted by sugarcane pre-harvest burning most of the time but also by bagasse combustion in sugar mills to a lesser extent. Levoglucosan and mannosan emissions factors from bagasse combustion have not been reported so far. We hypothesize that, even if these were very small, levoglucosan and mannosan combustion emissions might not be negligeable as CRV sugarcane biomass yields are very high and most of the harvested sugarcane bagasse is combusted for electric power and steam production.

\subsection{Polycyclic Aromatic Hydrocarbons (PAH)}

A total of 22 PAHs were measured in each sample collected at Palmira, including the 16 PAHs listed as human health priority pollutants by WHO and US-EPA (Yan et al., 2004). The total PAH concentration was $5.6 \pm 2.9 \mathrm{ng} \mathrm{m}^{-3}$ (min: $2.3 \mathrm{ng} \mathrm{m}^{-3}-\max$ : $15.8 \mathrm{ng} \mathrm{m}^{-3}$ ). Figure 5a shows the PAH concentration variability during the sampling campaign (mean and standard deviation are available on Table S2). The most abundant PAH were FLE $(44.2 \% \pm 11.9 \%$ total concentration share), ANT $(9,10)$ $(10.0 \% \pm 4.5 \%), \operatorname{BbF}(7.4 \% \pm 2.3 \%)$, BghiP $(6.7 \% \pm 2.4 \%)$, IcdP $(6.4 \% \pm 1.9 \%)$, CPY $(6.0 \% \pm 2.3 \%)$, FLO (9H) $(5.4 \% \pm 3.1 \%)$, $\mathrm{BeP}(4.6 \% \pm 1.3 \%)$, and $\mathrm{BaP}(4.4 \% \pm 1.6 \%)$, which accounted for $95.1 \%$ of the total $\mathrm{PAH}$ concentration(Figure $5 \mathrm{~b}$ ). Three-ring PAHs were the most abundant (59.04\% of total PAH). Put together, five- and six- ring PAHs accounted for an additional $38.44 \%$. The less abundant PAH group was the four-ring (2.52\%). A previous study in CRV, carried out by Romero et al. (2013), but on PM 10 samples, showed higher FLT, PYR and PHE concentrations in areas highly exposed to sugarcane preharvest burning compared to other locations. In contrast, $\mathrm{PM}_{2.5}$ FLE concentrations in this research were significantly higher than those in $\mathrm{PM}_{10}$ by Romero et al. (2013), while PYR and PHE levels were similar .

The carcinogenic species BaP, BbF, BkF, BaA, BghiP, FLE, CPY and BeP were identified in all the $\mathrm{PM}_{2.5}$ samples. $\mathrm{BaP}$ is a reference for PAH carcinogenicity (WHO, 2013a) that is used as PAH exposure metrics, known as the BenzoaPyreneequivalent carcinogenic potency (BaPE). We calculated BaPE using the toxic equivalent factors (TEF) proposed by Nisbet and LaGoy (1992) and (Malcolm and Dobson, 1994). PAH concentrations were multiplied by TEF and then added to estimate the carcinogenic potential of $\mathrm{PM}_{2.5}$-bounded PAH. The mean carcinogenicity level at Palmira, expressed as BaP-TEQ, was 0.4 $\pm 0.2 \mathrm{ng} \mathrm{m}^{-3}$ (min: $0.1 \mathrm{ng} \mathrm{m}^{-3}$ - max: $1.4 \mathrm{ng} \mathrm{m}^{-3}$ ). Only one sample exceeded the Colombian annual limit of $1 \mathrm{ng} \mathrm{m}^{-3}$ but most of them exceeded the WHO reference level of $0.12 \mathrm{ng} \mathrm{m}^{-3}$. The mutagenic potential of PAH (BaP-MEQ) was estimated using the mutagenic equivalent factors (MEF) reported for Durant et al., (1996). The average BaP-MEQ was $0.5 \pm 0.3 \mathrm{ng} \mathrm{m}^{-3}$ (min: $0.2 \mathrm{ng} \mathrm{m}^{-3}$ - max: $1.8 \mathrm{ng} \mathrm{m}^{-3}$ ). These levels are comparable to those measured in $\mathrm{PM}_{2.5}$ by Mugica-Álvarez et al., (2016) in Veracruz (México) but during the sugarcane non-harvest period. $\mathrm{PM}_{10}$ BaP-MEQ levels in Araraquara (Brazil) (de Andrade et al., 2010; De Assuncao et al., 2014) were twice as high as those found in. This suggest that year-long sugarcane pre-harvest burning in CRV leads to lower mutagenic potentials compared to those at locations where the harvesting period is shorter (zafra) thus with higher burning rates. We estimated the average BaP-TEQ and BaP-MEQ concentrations in CRV according 
to their exposure to sugarcane burning products from Romero et al., (2013) data and used as a benchmark to our measurements,. $\mathrm{PM}_{10}$-bound BaP-TEQ and BaP-MEQ levels for areas not directly exposed to sugarcane burning were $0.16 \mathrm{ng} \mathrm{m}^{-3}$ and $=0.21$ $\mathrm{ng} \mathrm{m}^{-3}$, respectively. Toxicity and mutagenicity due to $\mathrm{PM}_{10}$-bound PAHs were a factor 4 higher at areas directly exposed to sugarcane burning. It is reasonable to assume that PAHs are largely bound to fine aerosol $(<2.5 \mu \mathrm{m})$, thus that our measurements are comparable to (Romero et al., 2013). If so, our site at Palmira would be at an intermediate exposure condition, higher than areas not directly exposed to sugarcane burning but lower than exposed zones.

Ratios among different PAHs have been extensively used to distinguish between traffic and other PAH sources. We used the diagnostic ratios presented by Ravindra et al. (2008) and Tobiszewski and Namieśnik (2012a) to better understand the contribution of sources to $\mathrm{PM}_{2.5}$ in $\mathrm{CRV}$. The benzo(e)pyrene ratio to the sum of benzo(e)pyrene and benzo(a) pyrene is used as an aerosol aging indicator. Local or "fresh" aerosols have $[\mathrm{BeP}] /([\mathrm{BeP}]+[\mathrm{BaP}])$ ratios around 0.5 , while aged aerosols can have ratios as low as cero as a result of photochemical decomposition and oxidation. The $[\mathrm{BeP}] /([\mathrm{BeP}]+[\mathrm{BaP}])$ ratio at Palmira was $0.51 \pm 0.04$, with a majority $(84.4 \%, \mathrm{n}=38)$ of fresh samples a minor fraction $(15.6 \%, \mathrm{n}=7)$ of photochemically-degraded samples.

Other two diagnostic ratios were used to assess the prevalence of traffic as $\mathrm{PM}_{2.5}$ source. The first ratio one used IcdP and BghiP, two automobile emissions markers (Miguel and Pereira, 1989). Values higher than 0.5 for the IcdP ratio to the sum of IcdP and BghiP, [IdcP]/([IdcP]+[BghiP]), indicate aged particles (Tobiszewski and Namieśnik, 2012) generated by coal, grass or wood burning (Yunker et al., 2002). The second ratio is $[\mathrm{BaP}] /[\mathrm{BghiP}]$. Ratios higher than 0.6 are indicative of traffic emissions (Tobiszewski and Namieśnik, 2012). . At Palmira, the [IdcP]/([IdcP]+[BghiP]) and [BaP]/[BghiP] ratios were 0.48 \pm 0.04 and $0.69 \pm 0.13$, which indicates that $\sim 63 \%$ of the samples originated from combustion of oil products $(\mathrm{n}=30)$, and $\sim 36 \%$ came from non-traffic sources, like wood, grass, or coal $(n=15)$.

Also, the structure and size of PAHs are indicative of their sources. PAHs with low molecular weight (LMW) (two or three aromatic rings) has been reported as tracers of wood, grass and fuel oil combustion, while the PAHs of medium molecular weight (MMW) (four rings) and high molecular height (HMW) (five and six rings) are associated with coal combustion and vehicular emissions. The ratio between LMW ratio to the sum of MMW and HMW, LMW/(MMW+HMW), is used for source identification. Ratios lower than one are indicative oil products combustion, while ratios larger than one are associated to coal and biomass combustion (Tobiszewski and Namieśnik, 2012). The ratio at Palmira, LMW/(MMW+HMW) $=1.43 \pm 1.00$, was rather variable but suggests that a large fraction of PAHs in CRV (82.2\% of samples) were generated by biomass burning or combustion, as coal combustion is quite limited nowadays. Just one in five samples (17.8\%) have PAHs attributable to oil products combustion. 
Sugarcane-burning emitted PAHs are mainly of low molecular weight, especially of two ( $66 \%$ of PAHs) and three rings ( $27 \%$ ), among which FLE, PHE and ANT are the most emitted, according to Hall et al. (2012) chemical profile. The relative abundance of three-ring PAHs (Figure 5) in CRV's $\mathrm{PM}_{2.5}$ is likely due open-field sugarcane pre-harvest burning to major extent and to controlled bagasse combustion for electric power and steam production to a lesser extent.

\section{The highest concentrations of PAH were observed on $10^{\text {th }}$ August and $11^{\text {th }}$ September 2018 with levels of $15.8 \mathrm{ng} \mathrm{m}^{-3}$ and 14.4} $\mathrm{ng} \mathrm{m}^{-3}$, respectively (Fig 5S). In particular, on $10^{\text {th }}$ August 2018 elevated concentrations of 5 and 6 rings PAHs were observed. a change in wind circulation pattern form previous day on (Fig S2), with a wind speed reduction and a predominance of winds from the north. Then on $11^{\text {th }}$ September 2018, we observed an increase of 3-ring PAHs and winds from NW at the average wind speed at the sampling location.

\section{This indicates that there were at least two types of sources. The abundance of HMW PAHs indicate fossil fuel combustion} sources, and LMW PAHs suggest that parts of these came from non-fossil fuel combustion sources.
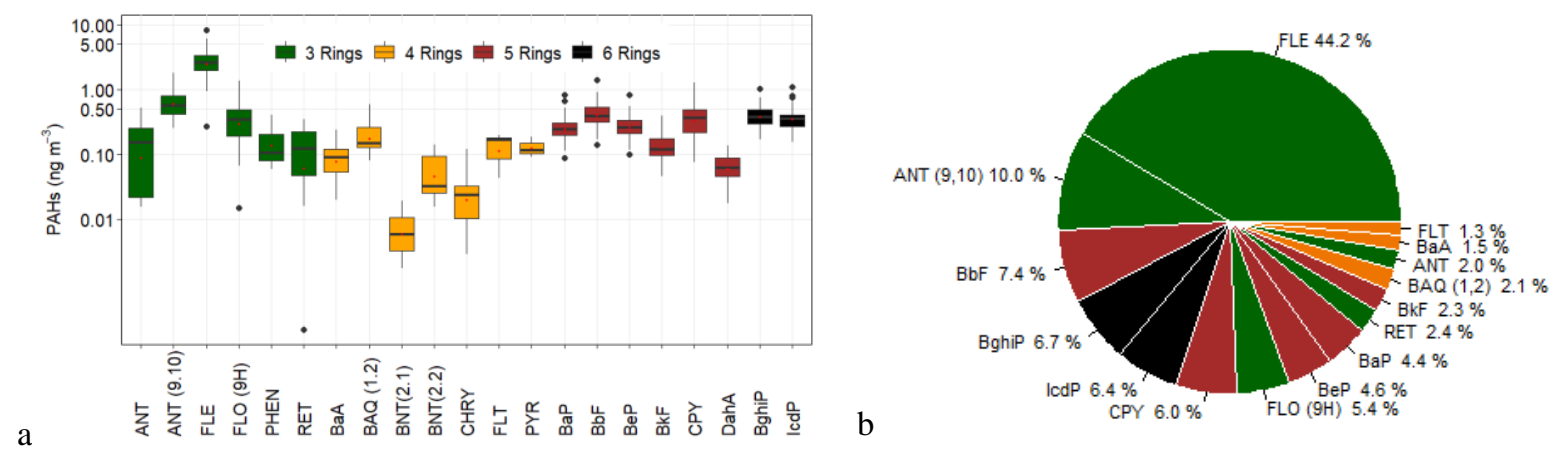

Figure 5. Abundance of PAHs measured in $\mathrm{PM}_{2.5}$ samples collected in CRV, represented by colors according to the number of rings of each PAH, green (tree rings), yellow (four rings), brown (five rings) and black (six rings). a) Box-plot of concentrations in $\mathrm{ng} \mathrm{m}^{-3}$, red dots represent mean concentrations of each PAH. b) pie-plot of the relative abundance of PAHs in $\mathrm{PM}_{2.5}$ samples.

\subsection{Alkanes}

A total of 16 alkanes ranging from $\mathrm{C}_{20}$ up to $\mathrm{C}_{34}$ were analyzed in this study and used to identify the presence of fossil fuel combustion and plant fragments in the $\mathrm{PM}_{2.5}$ samples. The abundance of total $\mathrm{n}$-alkanes during the whole sampling period was in the range of 13.0 to $88.45 \mathrm{ng} \mathrm{m}^{-3}$ with an average concentration of $40.36 \mathrm{ng} \mathrm{m}^{-3} \pm 18.82 \mathrm{ng} \mathrm{m}^{-3}$. In general, the high molecular weight $n$-alkanes such as $\mathrm{C}_{29}-\mathrm{C}_{31}$ were the most abundant. These are characteristic of vegetative detritus corresponding to plant fragments in airborne particle matter (Lin et al., 2010). The most abundant n-alkanes were $\mathrm{C}_{29}, \mathrm{C}_{30}$ and $\mathrm{C}_{31}$ (Fig 6.). 
Likewise, the carbon number maximum concentration $\left(C_{\max }\right)$ was $\mathrm{C}_{29}$ in $43 \%$ of samples and $\mathrm{C}_{31}$ in $28 \%$ of them. This result is consistent with the chemical profile of sugarcane burning reported by (Oros et al., 2006) with $\mathrm{C}_{\max }$ of $\mathrm{C}_{31}$.

The carbon preference index (CPI) and wax n-alkanes percentage (WNA\%) are parameters used to elucidate the origin of the $\mathrm{n}$-alkanes and infer whether emissions come from biogenic or anthropogenic sources. The CPI represents the ratio between odd and even carbon number n-alkanes. The equation used to calculate CPI in the present study is shown in Table 2, following the procedure reported by (Marzi et al., 1993). Values of CPI $\leq 1$ (or close to 1) indicate that n-alkanes are emitted from anthropogenic sources, while values higher than 1 indicate the influence of vegetative detritus in the $\mathrm{PM}_{2.5}$ samples (Mancilla et al., 2016). In this study, mean CPI was always greater than 1, with an average value of $1.22 \pm 0.18$ (min:1.02 - max:1.8) that is between the CPI for fossil fuel emissions of 1.0 (Caumo et al., 2020) and sugarcane burning of 2.1 (Oros et al., 2006), revealing the influence of several sources over the $\mathrm{PM}_{2.5}$ in the CRV.

Likewise, WNA\% represents the preference of odd n-alkanes in the sample. The odd n-alkanes, especially of higher molecular weight, are representative of plant wax related emissions. The waxes are present on the surface of plants, especially on the leaves, and they become airborne by a direct or indirect mechanism like wind action or biomass burning (Kang et al., 2018; Simoneit, 2002). In this research, the samples analyzed showed a preference for odd carbon on $\mathrm{C}_{27}, \mathrm{C}_{29}, \mathrm{C}_{31}$ and $\mathrm{C}_{33}$, which have higher concentrations than the next higher and lower even carbon number homologs, proving the biogenic contribution over the $\mathrm{PM}_{2.5}$ in the CRV. The WNA\% was calculated using the equation shown in Table 2 described by Yadav et al. (2013). A larger WNA\% represents the contribution from emissions of plant waxes or biomass burning. Otherwise, a smaller value represents that $n$-alkanes from petrogenic sources, known as petrogenic $n$-alkanes (PNA)\%. The mean WNA\% calculated for the $\mathrm{PM}_{2.5}$ samples collected from the CRV was $12.65 \% \pm 5.21 \%$ (min: $4.71 \%$ - max: $29.92 \%$ ) and can be defined as petrogenic inputs (PNA\%) that were $87.35 \%$ during the sampling period. The correlation between CPI and WNA was moderate $\left(\mathrm{r}^{2}=0.53\right)$ supporting a consistent meaning between these two parameters, and they are useful for assessing the plant wax contribution on $\mathrm{PM}_{2.5}$.

Overall, the total concentration of $\mathrm{n}$-alkanes of the $\mathrm{PM}_{2.5}$ in the CRV was lower than those reported in areas where the sugarcane is often burned in Brazil (Urban et al., 2016), although the behavior of the parameters of CPI and $\mathrm{C}_{\max }$ is similar. Compared with other urban areas in Latin American, the n-alkane concentration in the CRV was similar to that reported in the metropolitan zone of the Mexican valley (MZMV) for $\mathrm{PM}_{2.5}$ (Amador-Muñoz et al., 2011), and Bogota for $\mathrm{PM}_{10}$ and slightly lower than reported in Sao Paulo for $\mathrm{PM}_{10}$ (Vasconcellos et al., 2011). However, the CPI and WNA in these cities were smaller than in the CRV, because of the strong influence of vehicular emissions in these densely populated cities. The OC/EC ratio was moderately associated with WNA values $\left(\mathrm{r}^{2}=0.41\right)$, indicating that an increase of this ratio can be explained by the vegetative detritus contribution in the $\mathrm{PM}_{2.5}$, while the levoglucosan concentrations did not show correspondence to the CPI 

results indicated that $n$-alkanes found in this study came from several sources with a noticeable contribution from plant wax emissions. The parameters used to assess the source contribution of $\mathrm{PM}_{2.5}$ through $\mathrm{n}$-alkanes such CPI and WNA\%, were characteristic of aerosols collected in urban areas.

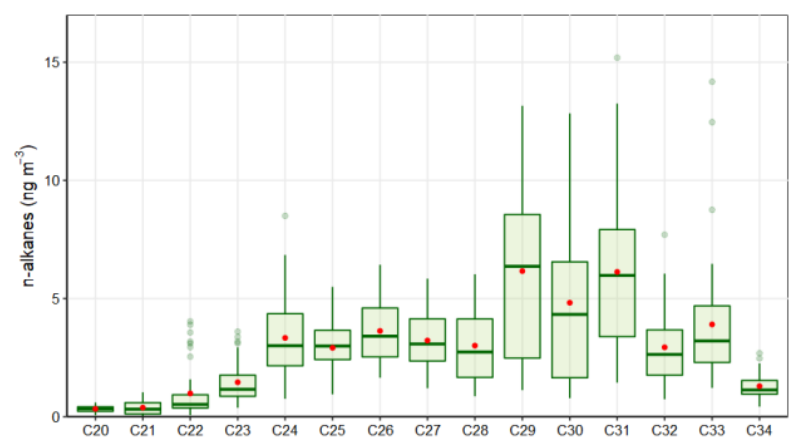

\subsection{PCA}

We applied a PCA to the chemical composition data to assess the latent factors controlling the $\mathrm{PM}_{2.5}$ concentrations in the CRV. This statistical tool was used to find the chemical species that describe each component and qualitatively associate these to potential sources of fine aerosol particles. In order to extract the number of components in a PCA many procedures exist, while one of the most common ones is the scree plot of successive eigenvalues for several components from which it is possible to identify the point where the proportion of the variance explained by each subsequent component drops off abruptly. Fig S7 shows the inflection point in component number four, explaining $45 \%$ of the chemical composition data variance. The addition of two following components allows describing $61 \%$ of the variance. Therefore, this study was conducted taking into account six components. Table 4 shows the loading for each chemical component assessment for the six components, where the 604 
https://doi.org/10.5194/acp-2021-601

Preprint. Discussion started: 3 August 2021

(c) Author(s) 2021. CC BY 4.0 License.

611 Table 4. Loading of PCA after varimax rotation. Loading with $|\mathrm{x}|<0.2$ was considered insignificant and removed, while 612 loading $|\mathrm{x}|<0.6$ is considered high and is printed bold.

\begin{tabular}{|c|c|c|c|c|c|c|}
\hline Principal Component & PC1 & PC2 & PC3 & PC4 & PC5 & PC6 \\
\hline 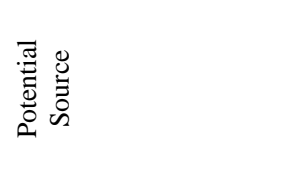 & 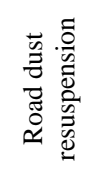 & 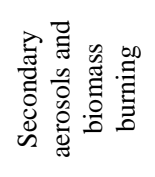 & 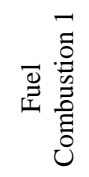 & 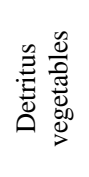 & 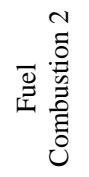 & 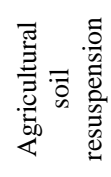 \\
\hline$\%$ variance explained & 13 & 11 & 11 & 10 & 9 & 7 \\
\hline$\%$ cumulative variance & 13 & 24 & 35 & 45 & 54 & 61 \\
\hline $\mathrm{OC}$ & 0.26 & 0.66 & 0.34 & 0.33 & 0.34 & 0.2 \\
\hline $\mathrm{EC}$ & & 0.73 & 0.39 & & 0.37 & \\
\hline $\mathrm{C}_{2} \mathrm{O}_{4}{ }^{2-}$ & & 0.65 & & 0.52 & & 0.39 \\
\hline $\mathrm{K}^{+} \quad$ (Water soluble ion) & & 0.39 & & 0.69 & & 0.3 \\
\hline $\mathrm{NO}_{2}^{-}$ & & 0.65 & 0.23 & 0.43 & & \\
\hline $\mathrm{F}^{-}$ & & 0.32 & & 0.36 & & \\
\hline $\mathrm{NO}_{3}^{+}$ & & 0.41 & & & & 0.64 \\
\hline $\mathrm{Cl}^{-}$ & & & & & & 0.61 \\
\hline $\mathrm{Ca}^{2+}$ (Water soluble ion $)$ & & 0.29 & & & & 0.74 \\
\hline $\mathrm{NH}_{4}^{+}$ & & 0.87 & & & & \\
\hline $\mathrm{SO}_{4}^{2-}$ & & 0.88 & & & & 0.26 \\
\hline Formate & & & & 0.34 & & 0.25 \\
\hline $\mathrm{Na}^{+}$ & & 0.33 & & & 0.25 & 0.36 \\
\hline $\mathrm{Mg}^{2+}$ & & 0.24 & 0.21 & & & 0.77 \\
\hline Methansulfonate & & 0.81 & & 0.23 & & \\
\hline $\mathrm{PO}_{4}^{3-}$ & & 0.38 & & & & \\
\hline \multicolumn{7}{|l|}{$\mathrm{Cr}$} \\
\hline $\mathrm{Ca}$ & 0.63 & & & & 0.2 & 0.41 \\
\hline K & 0.43 & 0.2 & & 0.62 & 0.2 & \\
\hline $\mathrm{Ti}$ & 0.39 & & & & & \\
\hline $\mathrm{Fe}$ & 0.74 & 0.35 & & & & \\
\hline $\mathrm{Sb}$ & 0.58 & & & & & \\
\hline $\mathrm{Mn}$ & 0.46 & 0.26 & & & & \\
\hline $\mathrm{Ba}$ & 0.73 & & 0.25 & & & \\
\hline $\mathrm{Se}$ & 0.40 & 0.55 & & & & \\
\hline $\mathrm{Zn}$ & 0.80 & & & & & \\
\hline As & & 0.57 & & & & \\
\hline
\end{tabular}


https://doi.org/10.5194/acp-2021-601

Preprint. Discussion started: 3 August 2021

(c) Author(s) 2021. CC BY 4.0 License.

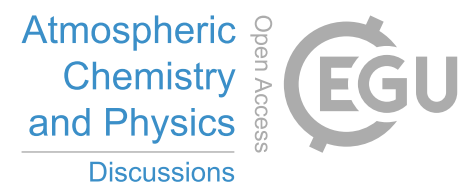

$0.25 \quad 0.35$

0.3

$\begin{array}{lll}0.33 & 0.29 & 0.29\end{array}$

$0.29 \quad 0.32$

0.85

0.84

$\begin{array}{lll}0.43 & 0.25 \quad \mathbf{0 . 6 7}\end{array}$

0.84

$\begin{array}{lll}0.34 & 0.33 & \mathbf{0 . 7 8}\end{array}$

$\begin{array}{lll}0.29 & 0.53 & \mathbf{0 . 6 5}\end{array}$

$\begin{array}{llll}0.24 & \mathbf{0 . 6 2} & 0.48 & 0.26\end{array}$

$\begin{array}{lll}\mathbf{0 . 6 9} & 0.33 & 0.26\end{array}$

$\mathbf{0 . 6 8} \quad 0.32 \quad 0.21$

$\mathbf{0 . 7 8} 0.3$

0.76

0.79

0.65

C34

FLT

PYR

BNT $(2,1)$

RET

0.33

PHEN

0.46

0.28

BAQ $(1,2)$

ANT

0.47

0.27

DahA

0.48

0.42

CPY

$\mathrm{BaA}$

IcdP

0.32

0.76

0.21

0.21

0.8

0.23

BghiP

$\mathrm{BkF}$

0.28

0.75

0.74

0.37

0.71

$0.37 \quad 0.23$

$\mathrm{BbF}$

0.32

$0.22 \quad 0.28$

0.83

0.27

$\mathrm{BeP}$

$\begin{array}{ll}0.27 & 0.21\end{array}$

$\mathrm{BaP}$

CHRY

0.42

0.8

0.32

0.83

0.34

0.47

0.32

0.73 


\begin{tabular}{|c|c|c|c|c|c|c|}
\hline ANT $(9,10)$ & & & & 0.2 & 0.25 & 0.2 \\
\hline FLO $(9 \mathrm{H})$ & & & 0.24 & 0.44 & & 0.42 \\
\hline BNT (2.2) & & & 0.48 & 0.2 & & \\
\hline Glucose & & 0.51 & & & 0.22 & \\
\hline Galactosan & & 0.31 & & 0.34 & 0.2 & 0.23 \\
\hline Levoglucosan & 0.27 & 0.41 & & 0.31 & & \\
\hline Arabitol & & 0.6 & & 0.3 & & \\
\hline Fructose & 0.38 & & 0.29 & & & \\
\hline
\end{tabular}

613

614 The first component rotated (PC1) explained 13\% of the total variance in the dataset. PC1 exhibited high loadings for the 615 metals $\mathrm{Zn}, \mathrm{Fe}, \mathrm{Ba}, \mathrm{Ca}, \mathrm{Sn}$, and a minor loading for $\mathrm{Sb}, \mathrm{Cu}, \mathrm{Mn}, \mathrm{K}$. These metals could have their origins in road dust resuspension because of roadside particles contained in non - exhaust and exhaust car emissions. For instance (Pant and Harrison, 2013) have shown the emission of $\mathrm{Zn}$ and $\mathrm{Ca}$ from tire wear and $\mathrm{Fe}, \mathrm{Ba}, \mathrm{Cu}, \mathrm{Sb}$, and $\mathrm{Sn}$ from brake wear. Also, this component explained the variance of the $n$-alkane $\mathrm{C}_{21}$ and a variance proportion of the HMW PAH (DahA, CPY, BkF, BghiP, $\mathrm{BbF}$ ) associated with vehicular emissions, together with $\mathrm{Cu}$ (Miguel and Pereira, 1989). Therefore, we call PC1 a component associated to road dust resuspension.

The second rotated component (PC2) explained $11 \%$ of the total variance. PC2 is a component associated with secondary aerosol formation and biomass burning. It was described by high loadings of the ions $\mathrm{SO}_{4}{ }^{2-}, \mathrm{NH}_{4}{ }^{+}$, methansulfonate, $\mathrm{C}_{2} \mathrm{O}_{4}{ }^{2-}$, and $\mathrm{NO}_{2}{ }^{-}$, along with a fraction of $\mathrm{EC}$ and $\mathrm{OC}$. Those ions also are observed in another region with sugarcane preharvest burning in Brazil (Allen et al., 2004), where the plume is enriched with $\mathrm{Cl}^{-}, \mathrm{NO}_{3}{ }^{-}$and $\mathrm{Na}^{+}$in the fine fraction of aerosol particles, while the ions $\mathrm{SO}_{4}{ }^{2-}$ and $\mathrm{C}_{2} \mathrm{O}_{4}{ }^{2-}$ are formed in the atmosphere during transport process due to the oxidation of $\mathrm{SO}_{2}$ and hydrocarbons. The important fraction of the variance of OC and especially EC explained by PC2 indicated the effect of an incomplete combustion process on this component, which together with the variance proportion explained by the Levoglucosan and $\mathrm{K}^{+}$indicated that the combustion process was associated with biomass burning. Also, PC2 is the one that best explained the variance of PAHs FLE and ANT, abundant in the chemical profile of sugarcane burning particles (Hall et al., 2012; Simoneit, 2002). Thus, PC2 seemed to be a combined effect of secondary aerosol formation and sugarcane burning.

The third rotated component (PC3) explained $11 \%$ of the variance and has high loadings for the PAH: $\mathrm{BbF}, \mathrm{BaP}, \mathrm{BeP}, \mathrm{BaA}$, $\mathrm{CPY}$, IcdP, BghiP, BkF, and the n-alkane $\mathrm{C}_{20} \mathrm{H}_{42}$ typically emitted during incomplete combustion of vehicle fuels (Andrade et al., 2012; Miguel and Pereira, 1989). A similar fraction of the variance of OC and EC was also explained with PC3, supporting the contribution of the combustion process. Thus, PC3 could be interpreted as a component derived from petroleum emissions by traffic. 
639 The fourth rotated component (PC4) explained $10 \%$ of the variance and had high loadings for $\mathrm{n}$-alkanes $>\mathrm{C}_{27}, \mathrm{~K}^{+}$and $\mathrm{K}$. The $\mathrm{n}$-alkanes $>\mathrm{C}_{25}$ are frequently associated with detritus and vegetable waxes. We explained the emission of the higher molecular weight $n$-alkanes to the biomass present in the region used by the agriculture industry and the abundance of nature present in the CRV. Therefore, we named PC4 a component associated with detritus vegetables.

The fifth rotated component (PC5) explained $9 \%$ of the variance, where $\mathrm{C}_{22}$ to $\mathrm{C}_{27}$ alkanes had high loadings. These fractions were associated with anthropogenic emissions (Kang et al., 2018). Thus, PC5 could be interpreted as a component derived from anthropogenic emissions. In addition, PC5 explained a variance proportion of some species associated with vehicular engine combustion, such as BghiP, BkF, BbF, characteristics of gasoline vehicles (Kuo et al., 2013) joint to EC and OC derivates from incomplete combustion. In summary, the components PC2, PC3 and PC5 describe the variance of EC, meaning the impact of incomplete combustion present in the region.

The sixth rotated component (PC6) explains $7 \%$ of the variance exhibiting high loadings for $\mathrm{Mg}^{2+}, \mathrm{Ca}^{2+}, \mathrm{FLE}, \mathrm{NO}_{3}{ }^{+}$, and $\mathrm{Cl}^{-}$ and moderate for others such as $\mathrm{C}_{2} \mathrm{O}_{4}{ }^{2-}, \mathrm{Na}^{+}, \mathrm{K}^{+}$. Particularly, the ions $\mathrm{Cl}^{-}, \mathrm{NO}_{3}{ }^{+}, \mathrm{K}^{+}$increase during biomass burning (Ryu et al., 2004). In addition, PC6 strongly explained the variance of calcium as water soluble ions and a fraction of the trace metal, therefore the erosion of soil could be considered as an activity that explained PC6. After preharvest biomass burning and fires as a tool to prepare the land for the next crops the soil erosion can increase because of the reduction of vegetation. Therefore, compounds associated with soil erosion and derivates of biomass burning can simultaneously affect the soil erosion and the chemical composition of $\mathrm{PM}_{2.5}$.

The PCA results showed there was no dominant component that explained the variance of chemical species contained in $\mathrm{PM}_{2.5}$ in CRV. Instead, many components have roles equally important that are associated with road dust derived from traffic, the formation of secondary aerosol particles and biomass combustion, petroleum combustion associated with vehicular exhaust, and the presence of vegetative detritus and agriculture soil resuspended by wind erosion. Sugarcane burning was not identified as an individual component that can be explained because the open sugarcane burns happened continuously during the sampling, so they became a background source for this study that very likely was included in the secondary formation as another background source. However, the carbohydrates contained in $\mathrm{PM}_{2.5}$ was linked to the characteristic species of secondary aerosol formation and vegetative detritus. Therefore the secondary pollutants could also originate from the burning of sugarcane in the CRV, similar to the results reported by (Vasconcellos et al., 2007) in Brazil. 
$\mathrm{PM}_{2.5}$ samples collected in the Cauca River Valley (CRV), Colombia, were analyzed to determine the main chemical components of fine aerosol particles and to qualitatively identify aerosol sources using ratios and principal component analysis (PCA). The main $\mathrm{PM}_{2.5}$ components were organic material (52.99\%here), followed by ammonium sulfate (16.12\%here) and elemental carbon (6.95\%here). The contribution of secondary organic material and inorganic salts was found to be significant and likely related to biomass burning and agricultural practices and estimated secondary aerosol formation was estimation of. EC and PAHs concentrations confirm the presence of incomplete combustion process in CRV. Diagnostic ratios applied to organic compounds indicate that $\mathrm{PM}_{2.5}$ was emitted locally and had contributions of pyrogenic and petrogenic sources. In addition, levoglucosan and mannosan levels showed that biomass burning was ubiquitous during the sampling period. Fluoranthene (FLE) was the most abundant PAH, confrieming the strong influence of sugarcane burning. Five- and six-ring PAH associated with vehicular emissions were also abundant in $\mathrm{PM}_{2.5}$. Our measurements point to sugarcane pre-harvest burning as the main source of PAHs in CRV. The comparison of $\mathrm{PM}_{2.5}$ concentrations and mutagenic potentials suggest that year-long sugarcane pre-harvest burning in CRV, which is also conducted on less than half of the harvested area (34\% in 2018) and over limited plots sizes ( $\sim 6$ ha median), leads to lower atmospheric pollutant burdens and mutagenic potentials compared to those at locations where the harvesting period is shorter (zafra) thus with higher burning rates.

Several sources were identified through PCA, including road dust, secondary aerosol particles, and biomass combustion, vehicle exhaust, vegetative detritus and resuspended agricultural soil likely induced by pre-harvest burning. Not one of these sources was dominant nor explained the chemical species variance of measured $\mathrm{PM}_{2.5}$. Sugarcane burning was not identified as an independent source, but it was found related to the secondary aerosol formation component on PCA. This link between sugarcane burning emissions and secondary aerosol formation requires further investigation. We found that the effects of agriculture on CRV's air quality, particularly of sugarcane preharvest burning are non-trivial. Besides primary particles, this activity generates SOA precursors, induces soil resuspension and is closely tied to diesel emissions during harvesting.

Author contribution: RJ, GR-S, and NR conceived and managed the project. LM-F, ACV-B, GR-S, and RJ set the instruments up and performed the aerosol sampling. LM-F carried out the sample chemical analysis at TROPOS with the guidance and support of DvP, MvP, KW and HH. LM-F and ACV-B analyzed the measurement results, including PCA and other techniques with the support of DvP and RJ. LM-F, RJ, NR and ACV-B prepared the manuscript with substantial contributions from all the authors. 
Acknowledgments: The authors gratefully acknowledge the financial support from the Universidad Nacional de Colombia Sede Palmira ([Impacto de la quema de caña de azúcar en la calidad del aire del Valle Geografico del Río Cauca] CACIQUE project Hermes \# 37718) and Leibniz Institute for Tropospheric Research (TROPOS) for analytical support. This project was supported by EU granted the mobility project PAPILA. We thank Susanne Fuchs, Anke Roedger, Sylvia Haferkorn, and Kornelia Pielok for their technical assistance in the chemical analysis of samples. We acknowledge Pablo Gutierrez for his contributions in the processing of open sugarcane burning base data.

\section{References}

Abdurrahman, M. I., Chaki, S. and Saini, G.: Stubble burning: Effects on health \& environment, regulations and management practices, Environ. Adv., 2(September), 100011, https://doi.org/10.1016/j.envadv.2020.100011, 2020. Agarwal, A., Satsangi, A., Lakhani, A. and Kumari, K. M.: Seasonal and spatial variability of secondary inorganic aerosols in PM2.5 at Agra: Source apportionment through receptor models, Chemosphere, 242, 125132, https://doi.org/10.1016/j.chemosphere.2019.125132, 2020.

Allen, A. G., Cardoso, A. A. and Da Rocha, G. O.: Influence of sugar cane burning on aerosol soluble ion composition in Southeastern Brazil, Atmos. Environ., 38(30), 5025-5038, https://doi.org/10.1016/j.atmosenv.2004.06.019, 2004.

Amador-Muñoz, O., Villalobos-Pietrini, R., Miranda, J. and Vera-Avila, L. E.: Organic compounds of PM2.5 in Mexico Valley: Spatial and temporal patterns, behavior and sources, Sci. Total Environ., 409(8), 1453-1465, https://doi.org/10.1016/j.scitotenv.2010.11.026, 2011.

Andrade, M. D. F., Miranda, R. M. De, Fornaro, A., Kerr, A., Oyama, B., Andre, P. A. De and Saldiva, P.: Vehicle emissions and PM2.5 mass concentrations in six Brazilian cities, Air Qual. Atmos. Heal., 5, 79-88, https://doi.org/10.1007/s11869-0100104-5, 2012.

de Andrade, S. J., Cristale, J., Silva, F. S., Julião Zocolo, G. and Marchi, M. R. R.: Contribution of sugar-cane harvesting season to atmospheric contamination by polycyclic aromatic hydrocarbons (PAHs) in Araraquara city, Southeast Brazil, Atmos. Environ., 44(24), 2913-2919, https://doi.org/10.1016/j.atmosenv.2010.04.026, 2010.

Andreae, M. O.: Soot Carbon and Excess Fine Potassium : Long-Range Transport of Combustion-Derived Aerosols., 1983.

Aneja, V. P., Schlesinger, W. H. and Erisman, J. W.: Farming pollution, Nat. Geosci., 1(7), 409-411, https://doi.org/10.1038/ngeo236, 2008.

Aneja, V. P., Schlesinger, W. H. and Erisman, J. W.: Effects of agriculture upon the air quality and climate: Research, policy, and regulations, Environ. Sci. Technol., 43(12), 4234-4240, https://doi.org/10.1021/es8024403, 2009.

Asocaña: Aspectos Generales del Sector Agroindustrial de la Caña 2017 - 2018. Informe Anual. https://www.asocana.org, 2018.

Asocaña: Aspectos generales del sector agroindustial de la caña Informe anual 2018-2019. https://www.asocana.org/documentos/2352019-D0CA1EED- 
00FF00,000A000,878787,C3C3C3,0F0F0F,B4B4B4,FF00FF,2D2D2D,A3C4B5.pdf, last access: 20 May 2020, 2019. Asocaña: Somos azucar y mucho más - Informe Anual 2019 - 2020, Cali., 2020.

De Assuncao, J. V., Pesquero, C. R., Nardocci, A. C., Francisco, A. P., Soares, N. S. and Ribeiro, H.: Airborne polycyclic aromatic hydrocarbons in a medium-sized city affected by preharvest sugarcane burning and inhalation risk for human health, J. Air Waste Manag. Assoc., 64(10), 1130-1139, https://doi.org/10.1080/10962247.2014.928242, 2014.

Begam, G. R., Vachaspati, C. V., Ahammed, Y. N., Kumar, K. R., Reddy, R. R., Sharma, S. K., Saxena, M. and Mandal, T. K.: Seasonal characteristics of water-soluble inorganic ions and carbonaceous aerosols in total suspended particulate matter at a rural semi-arid site, Kadapa (India), Environ. Sci. Pollut. Res., 24(2), 1719-1734, https://doi.org/10.1007/s11356-016-7917$1,2016$.

Cardozo-Valencia, A., Saa, G. R., Hernandez, A. J., Lopez, G. R. and Jimenez, R.: Distribución espaciotemporal y estimación de emisiones por quema precosecha de caña de azúcar en el Valle del Cauca, Conf. Proc. - Congr. Colomb. y Conf. Int. Calid. Aire y Salud Publica, CASAP 2019, https://doi.org/10.1109/CASAP.2019.8916696, 2019.

Caumo, S., Bruns, R. E. and Vasconcellos, P. C.: Variation of the distribution of atmospheric n-alkanes emitted by different fuels' combustion, Atmosphere (Basel)., 11(6), 1-19, https://doi.org/10.3390/atmos11060643, 2020.

Cavalli, F., Viana, M., Yttri, K. E., Genberg, J. and Putaud, J.: Toward a standardised thermal-optical protocol for measuring atmospheric organic and elemental carbon: the EUSAAR protocol, Atmos. Meas. Tech., 3, 79-89, https://doi.org/10.5194/amt-3-79-2010, 2010.

Chow, J. C., Lowenthal, D. H., Chen, L. W. A., Wang, X. and Watson, J. G.: Mass reconstruction methods for PM2.5: a review, Air Qual. Atmos. Heal., 8(3), 243-263, https://doi.org/10.1007/s11869-015-0338-3, 2015.

Clegg, S. L., Brimblecombe, P. and Wexler, A. S.: Thermodynamic Model of the System H+-NH4+-SO42--NO3--H2O at Tropospheric Temperatures, J. Phys. Chem. A, 102(12), 2137-2154, https://doi.org/10.1021/jp973042r, 1998.

Criollo, J. and Daza, N.: Evaluación de los niveles de concentración de metales en PM 10 producto de la quema de biomasa en el valle geográfico del rio Cauca, La Salle University https://ciencia.lasalle.edu.co/ing_ambiental_sanitaria/135\%0AThis, 2011.

Dabek-Zlotorzynska, E., Dann, T. F., Kalyani Martinelango, P., Celo, V., Brook, J. R., Mathieu, D., Ding, L. and Austin, C. C.: Canadian National Air Pollution Surveillance (NAPS) PM2.5 speciation program: Methodology and PM2.5 chemical composition for the years 2003-2008, Atmos. Environ., 45(3), 673-686, https://doi.org/10.1016/j.atmosenv.2010.10.024, 2011.

Durant, J. L., Busby Jr, W. F., Lafleur, A. L., Penman, B. W. and Crespi, C. L.: Human cell mutagenicity of oxygenated, nitrated and unsubstituted polycyclic aromatic hydrocarbons associated with urban aerosols, Mutat. Res. - Genet. Toxicol., 371(3-4), 123-157, https://doi.org/10.1016/S0165-1218(96)90103-2, 1996.

El-Zanan, H. S., Lowenthal, D. H., Zielinska, B., Chow, J. C. and Kumar, N.: Determination of the organic aerosol mass to organic carbon ratio in IMPROVE samples, Chemosphere, 60(4), 485-496, 
https://doi.org/10.1016/j.chemosphere.2005.01.005, 2005.

Engling, G., Lee, J. J., Tsai, Y.-W., Lung, S.-C. C., Chou, C. C.-K. and Chan, C.-Y.: Size-Resolved Anhydrosugar Composition in Smoke Aerosol from Controlled Field Burning of Rice Straw, Aerosol Sci. Technol., 43(7), 662-672, https://doi.org/10.1080/02786820902825113, 2009. FAO: FAOSTAT, http://www.fao.org/faostat/en/\#data/QC, last access: 21 July 2021, 2020.

Fomba, K. W., Müller, K., Van Pinxteren, D. and Herrmann, H.: Aerosol size-resolved trace metal composition in remote northern tropical atlantic marine environment: Case study cape verde islands, Atmos. Chem. Phys., 13(9), 4801-4814, https://doi.org/10.5194/acp-13-4801-2013, 2013.

Fomba, K. W., van Pinxteren, D., Müller, K., Spindler, G. and Herrmann, H.: Assessment of trace metal levels in size-resolved particulate matter in the area of Leipzig, Atmos. Environ., 176, https://doi.org/10.1016/j.atmosenv.2017.12.024, 2018. Franzin, B. T., Guizellini, F. C., de Babos, D. V., Hojo, O., Pastre, I. A., Marchi, M. R. R., Fertonani, F. L. and Oliveira, C. M. R. R.: Characterization of atmospheric aerosol (PM10 and PM2.5) from a medium sized city in São Paulo state, Brazil, J. Environ. Sci. (China), 89, 238-251, https://doi.org/10.1016/j.jes.2019.09.014, 2020.

Hall, D., Wu, C. Y., Hsu, Y. M., Stormer, J., Engling, G., Capeto, K., Wang, J., Brown, S., Li, H. W. and Yu, K. M.: PAHs, carbonyls, VOCs and PM 2.5 emission factors for pre-harvest burning of Florida sugarcane, Atmos. Environ., 55, 164-172, https://doi.org/10.1016/j.atmosenv.2012.03.034, 2012.

Herrera Murillo, J., Rodriguez Roman, S., Rojas Marin, J. F., Campos Ramos, A., Blanco Jimenez, S., Cardenas Gonzalez, B. and Gibson Baumgardner, D.: Chemical characterization and source apportionment of PM10 and PM2.5 in the metropolitan area of Costa Rica, Central America, Atmos. Pollut. Res., 4(2), 181-190, https://doi.org/10.5094/APR.2013.018, 2013.

Hopke, P. K.: Review of receptor modeling methods for source apportionment, J. Air Waste Manag. Assoc., 66(3), 237-259, https://doi.org/10.1080/10962247.2016.1140693, 2016.

Iinuma, Y., Engling, G., Puxbaum, H. and Herrmann, H.: A highly resolved anion-exchange chromatographic method for determination of saccharidic tracers for biomass combustion and primary bio-particles in atmospheric aerosol, Atmos. Environ., 43(6), 1367-1371, https://doi.org/10.1016/j.atmosenv.2008.11.020, 2009.

Janta, R., Sekiguchi, K., Yamaguchi, R., Sopajaree, K., Pongpiachan, S. and Chetiyanukornkul, T.: Ambient PM2.5, polycyclic aromatic hydrocarbons and biomass burning tracer in Mae Sot District, western Thailand, Atmos. Pollut. Res., 11(1), 27-39, https://doi.org/10.1016/j.apr.2019.09.003, 2019.

Jenkins, B. M., Turn, S. Q. and Williams, R. B.: Atmospheric emissions from agricultural burning in California: Determination of burn fractions, distribution factors, and crop-specific contributions, Agric. Ecosyst. Environ., 38(4), 313-330, https://doi.org/10.1016/0167-8809(92)90153-3, 1992.

Jorquera, H. and Barraza, F.: Source apportionment of ambient PM2.5 in Santiago, Chile: 1999 and 2004 results, Sci. Total Environ., 435-436, 418-429, https://doi.org/10.1016/j.scitotenv.2012.07.049, 2012.

Jorquera, H. and Barraza, F.: Source apportionment of PM10 and PM2.5 in a desert region in northern Chile, Sci. Total 
Environ., 444, 327-335, https://doi.org/10.1016/j.scitotenv.2012.12.007, 2013.

Kang, M., Ren, L., Ren, H., Zhao, Y., Kawamura, K., Zhang, H., Wei, L., Sun, Y., Wang, Z. and Fu, P.: Primary biogenic and anthropogenic sources of organic aerosols in Beijing, China: Insights from saccharides and n-alkanes, Environ. Pollut., 243, 1579-1587, https://doi.org/10.1016/j.envpol.2018.09.118, 2018.

Karagulian, F., Belis, C. A., Francisco, C., Dora, C., Prüss-ustün, A. M., Bonjour, S., Adair-rohani, H. and Amann, M.: Contributions to cities ' ambient particulate matter ( PM ): A systematic review of local source contributions at global level, Atmos. Environ., 120, 475-483, https://doi.org/10.1016/j.atmosenv.2015.08.087, 2015.

Khedidji, S., Müller, K., Rabhi, L., Spindler, G., Fomba, K. W., Van Pinxteren, D., Yassaa, N. and Herrmann, H.: Chemical characterization of marine aerosols in a south mediterranean coastal area located in Bou Ismaïl, Algeria, Aerosol Air Qual. Res., 20(11), 2448-2473, https://doi.org/10.4209/aaqr.2019.09.0458, 2020.

Kundu, S. and Stone, E. A.: Composition and sources of fine particulate matter across urban and rural sites in the Midwestern United States, Environ. Sci. Process. Impacts, 16(6), 1360-1370, https://doi.org/10.1039/c3em00719g, 2014.

Kuo, C. Y., Chien, P. S., Kuo, W. C., Wei, C. T. and Rau, J. Y.: Comparison of polycyclic aromatic hydrocarbon emissions on gasoline- and diesel-dominated routes, Environ. Monit. Assess., 185(7), 5749-5761, https://doi.org/10.1007/s10661-0122981-6, 2013.

Lara, L. L., Artaxo, P., Martinelli, L. A., Camargo, P. B., Victoria, R. L. and Ferraz, E. S. B.: Properties of aerosols from sugar-cane burning emissions in Southeastern Brazil, Atmos. Environ., 39(26), 4627-4637, https://doi.org/10.1016/j.atmosenv.2005.04.026, 2005.

Lee, S., Wang, Y. and Russell, A. G.: Assessment of secondary organic carbon in the southeastern United States: A review, J. Air Waste Manag. Assoc., 60(11), 1282-1292, https://doi.org/10.3155/1047-3289.60.11.1282, 2010.

Li, X., Wang, L., Ji, D., Wen, T., Pan, Y., Sun, Y. and Wang, Y.: Characterization of the size-segregated water-soluble inorganic ions in the Jing-Jin-Ji urban agglomeration: Spatial/temporal variability, size distribution and sources, Atmos. Environ., 77, 250-259, https://doi.org/10.1016/j.atmosenv.2013.03.042, 2013.

Lin, L., Lee, M. L. and Eatough, D. J.: Review of recent advances in detection of organic markers in fine particulate matter and their use for source apportionment, J. Air Waste Manag. Assoc., 60(1), 3-25, https://doi.org/10.3155/1047-3289.60.1.3, 2010.

Lopez, M. E. and Howell, W. E.: Katabatic winds in the Equatorial Andes, J. Atmos. Sci., 24(1), 29-35, https://doi.org/doi.org/10.1175/1520-0469(1967)024<0029:KWITEA>2.0.CO;2, 1967.

Lyu, R., Shi, Z., Alam, M. S., Wu, X., Liu, D., Vu, T. V., Stark, C., Xu, R., Fu, P., Feng, Y. and Harrison, R. M.: Alkanes and aliphatic carbonyl compounds in wintertime PM2.5 in Beijing, China, Atmos. Environ., 202(November 2018), 244-255, https://doi.org/10.1016/j.atmosenv.2019.01.023, 2019.

MADS: Res. No 2254, Ministerio de Ambiente y Desarrollo Sostenible, Colombia., 2017.

Majra, J. P.: Air Quality in Rural Areas, in Chemistry, Emission Control, Radioactive Pollution and Indoor Air Quality, 
https://doi.org/10.5772/16890, , 2011.

Malcolm, H. M. and Dobson, S.: The calculation of an Environmental Assessment Level (EAL) for atmospheric PAHs using relative potencies., 1994.

Mancilla, Y., Mendoza, A., Fraser, M. P. and Herckes, P.: Organic composition and source apportionment of fine aerosol at Monterrey, Mexico, based on organic markers, Atmos. Chem. Phys., 16(2), 953-970, https://doi.org/10.5194/acp-16-9532016, 2016.

Marzi, R., Torkelson, B. E. and Olson, R. K.: A revised carbon preference index, Org. Geochem., 20(8), 1303-1306, https://doi.org/10.1016/0146-6380(93)90016-5, 1993. Mesa S., Ó. J. and Rojo H., J. D.: On the general circulation of the atmosphere around Colombia, Rev. la Acad. Colomb. Ciencias Exactas, Fis. y Nat., 44(172), 857-875, https://doi.org/10.18257/RACCEFYN.899, 2020. Miguel, A. H. and Pereira, P. A. P.: Benzo(k)fluoranthene, benzo(ghi)perylene, and indeno(1, 2, 3-cd)pyrene: New tracers of automotive emissions in receptor modeling, Aerosol Sci. Technol., $10(2)$, 292-295,

\section{3} https://doi.org/10.1080/02786828908959265, 1989.

Mugica-Alvarez, V., Santiago-de la Rosa, N., Figueroa-Lara, J., Flores-Rodríguez, J., Torres-Rodríguez, M. and MagañaReyes, M.: Emissions of PAHs derived from sugarcane burning and processing in Chiapas and Morelos México, Sci. Total Environ., 527-528, 474-482, https://doi.org/10.1016/j.scitotenv.2015.04.089, 2015.

Mugica-Álvarez, V., Ramos-Guízar, S., Santiago-de la Rosa, N., Torres-Rodríguez, M. and Noreña-Franco, L.: Black Carbon and Particulate Organic Toxics Emitted by Sugarcane Burning in Veracruz, México, Int. J. Environ. Sci. Dev., 7(4), 290-294, https://doi.org/10.7763/ijesd.2016.v7.786, 2016.

Mugica-Álvarez, V., Hernández-Rosas, F., Magaña-Reyes, M., Herrera-Murillo, J., Santiago-De La Rosa, N., GutiérrezArzaluz, M., de Jesús Figueroa-Lara, J. and González-Cardoso, G.: Sugarcane burning emissions: Characterization and emission factors, Atmos. Environ., 193, 262-272, https://doi.org/10.1016/j.atmosenv.2018.09.013, 2018.

Neusüss, C., Pelzing, M., Plewka, A. and Herrmann, H.: A new analytical approach for size-resolved speciation of organic compounds in atmospheric aerosol particles: Methods and first results, J. Geophys. Res. Atmos., 105(D4), 4513-4527, https://doi.org/10.1029/1999JD901038, 2000.

Nisbet, I. C. T. and LaGoy, P. K.: Toxic equivalency factors (TEFs) for polycyclic aromatic hydrocarbons (PAHs), Regul. Toxicol. Pharmacol., 16(3), 290-300, https://doi.org/10.1016/0273-2300(92)90009-X, 1992.

Oros, D. R., Abas, M. R. bin, Omar, N. Y. M. J., Rahman, N. A. and Simoneit, B. R. T.: Identification and emission factors of molecular tracers in organic aerosols from biomass burning: Part 3. Grasses, Appl. Geochemistry, 21(6), 919-940, https://doi.org/10.1016/j.apgeochem.2006.01.008, 2006.

Ortiz, E. Y., Jimenez, R., Fochesatto, G. J. and Morales-Rincon, L. A.: Caracterización de la turbulencia atmosférica en una gran zona verde de una megaciudad andina tropical, Rev. la Acad. Colomb. Ciencias Exactas, Físicas y Nat., 43(166), 133, https://doi.org/10.18257/raccefyn.697, 2019. 
Pan, X., Ichoku, C., Chin, M., Bian, H., Darmenov, A., Colarco, P., Ellison, L., Kucsera, T., Da Silva, A., Wang, J., Oda, T. and Cui, G.: Six global biomass burning emission datasets: Intercomparison and application in one global aerosol model, Atmos. Chem. Phys., 20(2), 969-994, https://doi.org/10.5194/acp-20-969-2020, 2020.

Pant, P. and Harrison, R. M.: Estimation of the contribution of road traffic emissions to particulate matter concentrations from field measurements: A review, Atmos. Environ., 77, 78-97, https://doi.org/10.1016/j.atmosenv.2013.04.028, 2013.

Pereira, G. M., Oraggio, B., Teinilä, K., Custódio, D., Huang, X., Hillamo, R., Alves, C. A., Balasubramanian, R., Rojas, N. Y. and Sanchez-Ccoyllo, O.: A comparative chemical study of PM 10 in three Latin American cities : Lima, Medellín, ans São Paulo, Air Qual. Atmos. Heal., 12, 1141-1152, https://doi.org/10.1007/s11869-019-00735-3, 2019.

Pio, C., Cerqueira, M., Harrison, R. M., Nunes, T., Mirante, F., Alves, C., Oliveira, C., Sanchez de la Campa, A., Artínano, B. and Matos, M.: OC/EC ratio observations in Europe: Re-thinking the approach for apportionment between primary and secondary organic carbon, Atmos. Environ., 45(34), 6121-6132, https://doi.org/10.1016/j.atmosenv.2011.08.045, 2011.

Plaza, J., Artíñano, B., Salvador, P., Gómez-Moreno, F. J., Pujadas, M. and Pio, C. A.: Short-term secondary organic carbon estimations with a modified OC/EC primary ratio method at a suburban site in Madrid (Spain), Atmos. Environ., 45(15), 24962506, https://doi.org/10.1016/j.atmosenv.2011.02.037, 2011.

Ramírez, O., Sánchez de la Campa, A. M., Amato, F., Catacolí, R. A., Rojas, N. Y. and de la Rosa, J.: Chemical composition and source apportionment of PM10 at an urban background site in a high-altitude Latin American megacity (Bogota, Colombia), Environ. Pollut., 233, 142-155, https://doi.org/10.1016/j.envpol.2017.10.045, 2018.

Ravindra, K., Sokhi, R. and Van Grieken, R.: Atmospheric polycyclic aromatic hydrocarbons: Source attribution, emission factors and regulation, Atmos. Environ., 42(13), 2895-2921, https://doi.org/10.1016/j.atmosenv.2007.12.010, 2008.

Rojo H., J. D. and Mesa O., Ó. J.: A simple conceptual model for the heat induced circulation over Northern South America and Meso-America, Atmosphere (Basel)., 11(11), 1-14, https://doi.org/10.3390/atmos11111235, 2020.

Romero, D., Sarmiento, H. and Pachón, J. E.: Estimación de hidrocarburos aromáticos policíclicos y metales pesados asociados con la quema de caña de azúcar en el valle geográfico del río Cauca , Colombia, Rev. Épsilon, 21(2013), 57-82, 2013. Ryu, S. Y., Kim, J. E., Zhuanshi, H., Kim, Y. J. and Kang, G. U.: Chemical composition of post-harvest biomass burning aerosols in gwangju, Korea, J. Air Waste Manag. Assoc., 54(9), 1124-1137, https://doi.org/10.1080/10473289.2004.10471018, 2004.

Dos Santos, C. Y. M., Azevedo, D. de A. and De Aquino Neto, F. R.: Selected organic compounds from biomass burning found in the atmospheric particulate matter over sugarcane plantation areas, Atmos. Environ., 36(18), 3009-3019, https://doi.org/10.1016/S1352-2310(02)00249-2, 2002.

Schauer, J. J.: Sources contributions to atmospheric organic compound concentrations: Emissions measurments and model predictions, California Institute Technology, 1998.

SDA: Plan decenal de descontaminación del aire de Bogotá, Bogotá D.C. http://ambientebogota.gov.co/en/c/document_library/get_file?uuid=b5f3e23f-9c5f-40ef-912a- 
51a5822da320\&groupId=55886, 2010.

Simoneit, B. R. T.: Biomass burning - A review of organic tracers for smoke from incomplete combustion, Appl. Geochemistry, 17(3), 129-162, https://doi.org/10.1016/S0883-2927(01)00061-0, 2002.

Snider, G., Weagle, C. L., Murdymootoo, K. K., Ring, A., Ritchie, Y., Stone, E., Walsh, A., Akoshile, C., Anh, N. X., Balasubramanian, R., Brook, J., Qonitan, F. D., Dong, J., Griffith, D., He, K., Holben, B. N., Kahn, R., Lagrosas, N., Lestari, P., Ma, Z., Misra, A., Norford, L. K., Quel, E. J., Salam, A., Schichtel, B., Segev, L., Tripathi, S., Wang, C., Yu, C., Zhang, Q., Zhang, Y., Brauer, M., Cohen, A., Gibson, M. D., Liu, Y., Martins, J. V., Rudich, Y. and Martin, R. V.: Variation in global chemical composition of PM2.5: emerging results from SPARTAN, Atmos. Chem. Phys., 16(15), 9629-9653, https://doi.org/10.5194/acp-16-9629-2016, 2016.

Souza, D. Z., Vasconcellos, P. C., Lee, H., Aurela, M., Saarnio, K., Teinilä, K. and Hillamo, R.: Composition of PM2.5 and PM10 collected at Urban Sites in Brazil, Aerosol Air Qual. Res., 14(1), 168-176, https://doi.org/10.4209/aaqr.2013.03.0071, 2014.

Sutton, M. A., Billen, G., Bleeker, A., Erisman, J. W., Grennfelt, P., Grinsven, H. Van, Grizzetti, B., Howard, C. M. and Leip, A.: Technical summary Part I Nitrogen in Europe: the present position, in The European Nitrogen Assessment: Sources, Effects and Policy Perspectives, edited by M. A. Sutton, C. M. Howard, J. W. Erisman, G. Billen, A. Bleeker, P. Grennfelt, H. Van Grinsven, and B. Grizzetti, Cambridge University Press, Cambridge, https://doi.org/10.1017/CBO9780511976988.003, , 2011.

Szabó, J., Szabó Nagy, A. and Erdős, J.: Ambient concentrations of PM10, PM10-bound polycyclic aromatic hydrocarbons and heavy metals in an urban site of Györ, Hungary, Air Qual. Atmos. Heal., 8(2), 229-241, https://doi.org/10.1007/s11869015-0318-7, 2015.

Tobiszewski, M. and Namieśnik, J.: PAH diagnostic ratios for the identification of pollution emission sources, Environ. Pollut., 162, 110-119, https://doi.org/10.1016/j.envpol.2011.10.025, 2012.

Turpin, B. J. and Lim, H.: Species Contributions to PM2 . 5 Mass Concentrations : Revisiting Common Assumptions for Estimating Organic Mass, Aerosol Sci. Technol., 35:1(September 2014), 37-41, https://doi.org/http://dx.doi.org/10.1080/02786820119445, 2001.

Urban, R. C., Lima-Souza, M., Caetano-Silva, L., Queiroz, M. E. C., Nogueira, R. F. P., Allen, A. G., Cardoso, A. A., Held, G. and Campos, M. L. A. M.: Use of levoglucosan, potassium, and water-soluble organic carbon to characterize the origins of biomass-burning aerosols, Atmos. Environ., 61, 562-569, https://doi.org/10.1016/j.atmosenv.2012.07.082, 2012.

Urban, R. C., Alves, C. A., Allen, A. G., Cardoso, A. A., Queiroz, M. E. C. and Campos, M. L. A. M.: Sugar markers in aerosol particles from an agro-industrial region in Brazil, Atmos. Environ., 90(2014), 106-112, https://doi.org/10.1016/j.atmosenv.2014.03.034, 2014.

Urban, R. C., Alves, C. A., Allen, A. G., Cardoso, A. A. and Campos, M. L. A. M.: Organic aerosols in a Brazilian agroindustrial area: Speciation and impact of biomass burning, Atmos. Res., 169, 271-279, 
https://doi.org/10.1016/j.atmosres.2015.10.008, 2016.

Vargas, F. A., Rojas, N. Y., Pachon, J. E. and Russell, A. G.: PM10 characterization and source apportionment at two residential areas in Bogota, Atmos. Pollut. Res., 3(1), 72-80, https://doi.org/10.5094/APR.2012.006, 2012.

Vasconcellos, P. C., Balasubramanian, R., Bruns, R. E., Sanchez-Ccoyllo, O., Andrade, M. F. and Flues, M.: Water-soluble ions and trace metals in airborne particles over urban areas of the state of São Paulo, Brazil: Influences of local sources and long range transport, Water. Air. Soil Pollut., 186(1-4), 63-73, https://doi.org/10.1007/s11270-007-9465-2, 2007.

Vasconcellos, P. C., Souza, D. Z., Ávila, S. G., Araújo, M. P., Naoto, E., Nascimento, K. H., Cavalcante, F. S., Dos, M., Smichowski, P. and Behrentz, E.: Comparative study of the atmospheric chemical composition of three South American cities, Atmos. Environ., 45(32), 5770-5777, https://doi.org/10.1016/j.atmosenv.2011.07.018, 2011.

Victoria, J., Amaya, A., Rangel, H., Viveros, C., Cassalett, C., Carbonell, J., Quintero, R., Cruz, R., Isaacs, C., Larrahondo, J., Moreno, C., Palma, A., Posada, C., Villegas, F. and Gómez, L.: Características agronómicas y de productividad de la variedad Cenicaña Colombiana (CC) 85-92, Cali., 2002.

Villalobos, A. M., Barraza, F., Jorquera, H. and Schauer, J. J.: Chemical speciation and source apportionment of fine particulate matter in Santiago, Chile, 2013, Sci. Total Environ., 512-513, 133-142, https://doi.org/10.1016/j.scitotenv.2015.01.006, 2015. Wagner, R., Jähn, M. and Schepanski, K.: Wildfires as a source of airborne mineral dust - Revisiting a conceptual model using large-eddy simulation (LES), Atmos. Chem. Phys., 18(16), 11863-11884, https://doi.org/10.5194/acp-18-11863-2018, 2018. WHO Regional Office for Europe: Air quality guidelines for Europe, pp. 457-465, World Health Organization, Copenhagen, Denmark, https://doi.org/10.1525/9780520948068-070, , 2020.

World Health Organization: Review of evidence on health aspects of air pollution - REVIHAAP Project. http://www.euro.who.int/pubrequest\%0Ahttp://www.euro.who.int/_data/assets/pdf_file/0004/193108/REVIHAAP-Finaltechnical-report-final-version.pdf., 2013.

Wu, C. and Zhen Yu, J.: Evaluation of linear regression techniques for atmospheric applications: The importance of appropriate weighting, Atmos. Meas. Tech., 11(2), 1233-1250, https://doi.org/10.5194/amt-11-1233-2018, 2018.

Yadav, I. C. and Devi, N. L.: Biomass burning, regional air quality, and climate change, 2nd ed., Elsevier Inc., 2019.

Yadav, S., Tandon, A. and Attri, A. K.: Monthly and seasonal variations in aerosol associated n-alkane profiles in relation to meteorological parameters in New Delhi, India, Aerosol Air Qual. Res., 13(1), 287-300, https://doi.org/10.4209/aaqr.2012.01.0004, 2013.

Yan, J., Wang, L., Fu, P. P. and Yu, H.: Photomutagenicity of 16 polycyclic aromatic hydrocarbons from the US EPA priority pollutant list, Mutat. Res. - Genet. Toxicol. Environ. Mutagen., 557(1), 99-108, https://doi.org/10.1016/j.mrgentox.2003.10.004, 2004.

Yunker, M. B., Macdonald, R. W., Vingarzan, R., Mitchell, H., Goyette, D. and Sylvestre, S.: PAHs in the Fraser River basin: a critical appraisal of PAH ratios as indicators of PAH source and composition, Org. Geochem., 33, 489-515, https://doi.org/doi.org/10.1016/S0146-6380(02)00002-5, 2002. 